\title{
TU/e ENHOUEN

\section{Enzymatic synthesis and preliminary evaluation as coating of sorbitol-based, hydroxy-functional polyesters with controlled molecular weights}

\section{Citation for published version (APA):}

Gustini, L., Noordover, B. A. J., Gehrels, C., Dietz, C. H. J. T., \& Koning, C. E. (2015). Enzymatic synthesis and preliminary evaluation as coating of sorbitol-based, hydroxy-functional polyesters with controlled molecular weights. European Polymer Journal, 67, 459-475. https://doi.org/10.1016/j.eurpolymj.2014.12.025

DOI:

10.1016/j.eurpolymj.2014.12.025

Document status and date:

Published: 01/01/2015

\section{Document Version:}

Publisher's PDF, also known as Version of Record (includes final page, issue and volume numbers)

\section{Please check the document version of this publication:}

- A submitted manuscript is the version of the article upon submission and before peer-review. There can be important differences between the submitted version and the official published version of record. People interested in the research are advised to contact the author for the final version of the publication, or visit the DOI to the publisher's website.

- The final author version and the galley proof are versions of the publication after peer review.

- The final published version features the final layout of the paper including the volume, issue and page numbers.

Link to publication

\footnotetext{
General rights

- You may freely distribute the URL identifying the publication in the public portal. follow below link for the End User Agreement:

www.tue.nl/taverne

\section{Take down policy}

If you believe that this document breaches copyright please contact us at:

openaccess@tue.nl

providing details and we will investigate your claim.
}

Copyright and moral rights for the publications made accessible in the public portal are retained by the authors and/or other copyright owners and it is a condition of accessing publications that users recognise and abide by the legal requirements associated with these rights.

- Users may download and print one copy of any publication from the public portal for the purpose of private study or research.

- You may not further distribute the material or use it for any profit-making activity or commercial gain

If the publication is distributed under the terms of Article 25fa of the Dutch Copyright Act, indicated by the "Taverne" license above, please 


\title{
Enzymatic synthesis and preliminary evaluation as coating of sorbitol-based, hydroxy-functional polyesters with controlled molecular weights
}

\author{
Liliana Gustini $^{\text {a }}$, Bart A.J. Noordover ${ }^{\text {a,* }}$, Coen Gehrels ${ }^{b}$, Carin Dietz ${ }^{a}$, Cor E. Koning a,b \\ ${ }^{a}$ Laboratory of Polymer Materials, Eindhoven University of Technology, P.O. Box 513, 5600 MB Eindhoven, The Netherlands \\ ${ }^{\mathrm{b}}$ DSM Coating Resins, Ceintuurbaan 5, Zwolle, The Netherlands
}

\section{A R T I C L E I N F O}

\section{Article history:}

Received 24 October 2014

Received in revised form 12 December 2014

Accepted 16 December 2014

Available online 24 December 2014

\section{Keywords:}

Renewable polyester

Sorbitol

Enzymatic polycondensation

Poly(ester urethane)

Coatings

\begin{abstract}
A B S T R A C T
By using a combination of bio-based monomers (sorbitol, 1,10-decanediol and a range of dicarboxylic acids), a series of novel sorbitol-based polyesters was prepared by solvent-free enzymatic polycondensation using an immobilized form of Candida antarctica lipase $B$ (Novozyme 435). The aim was to prepare linear polyesters with pendant, curable hydroxyl groups along the polymer backbone. To achieve this, the polyester molecular weight was controlled by tuning the reaction time, enzyme loading and reaction stoichiometry. Extensive molecular and thermal characterization was performed, showing that the obtained polyesters were semi-crystalline materials with a low $T_{\mathrm{g}}$. The presence of sorbitol in the polyesters was confirmed through a qualitative investigation using MALDI-ToF-MS. The quantification of the sorbitol content in the polymers was achieved by inverse-gated decoupling ${ }^{13} \mathrm{C}$ NMR spectroscopy, while ${ }^{31} \mathrm{P}$ NMR provided information regarding the selectivity of CALB for the primary vs. the secondary hydroxyl groups. Moreover, ${ }^{31} \mathrm{P}$ NMR and potentiometric titration were utilized for the quantitative determination of the amount of carboxylic groups and hydroxyl functional groups present in the polyesters. The obtained hydroxyl-functional polyesters had suitable properties to be applied as solvent-borne coatings in terms of their molecular weight, functionality and thermal characteristics. Cross-linked coatings were prepared using different conventional curing agents, including two renewable diisocyanates (ethyl ester L-lysine diisocyanate and dimer fatty acid-based diisocyanate). The resulting poly(ester urethane) coatings were tested in terms of solvent resistance, hardness and resistance against rapid deformation, showing the beneficial effect of the implemented sorbitol on network formation.
\end{abstract}

(c) 2014 Elsevier Ltd. All rights reserved.

\section{Introduction}

The use of abundant, naturally occurring renewable compounds for chemical synthesis is an important strategy to reduce our dependence on petroleum-derived raw materials. An expanding range of chemicals can be produced from renewable resources starting from sources

\footnotetext{
* Corresponding author.

E-mail address: b.a.j.noordover@tue.nl (B.A.J. Noordover).
}

such as starch, cellulose and vegetable oils. Sugar-based biomass has the potential to serve as a widely available source of starting compounds for biobased polymers, as well as for bioenergy and biochemistry purposes [1]. One of the key areas targeted in the development of biomass conversion technologies is the production of new materials from renewable building blocks [2]. Much of the currently ongoing research is focused on utilizing existing building blocks coming from the second generation biomass stream (forestry and agricultural waste) for novel performance polymers. 
Due to its structural complexity, starch exhibits certain unique properties which are not encountered in other polysaccharides, such as granule swelling under heating. When dispersed in water upon heating, starch shows the particular ability to interact with a number of linear polar and non-polar molecules including fatty acids, fatty alcohols, monoglycerides and others. One of the most studied starch-derived saccharides is glucitol, a natural polyhydric sugar alcohol also known as sorbitol (see Scheme 1), and its derivatives sorbitan, isosorbide and galactitol [3]. Sorbitol is the most extracted sugar from starch [4] and cellulose [5]. It is increasingly utilized in non-food industries for applications such as textiles, packaging and as building block for commodity chemicals and renewable resins [3].

As a polyhydric alcohol monomer, sorbitol can in principle be directly used in polyester synthesis. However, the application of sugar-derived monomers in linear polyesters is challenging due to their multifunctional nature. Still, as sorbitol contains both primary and secondary OH-groups, it is possible to either convert most (or even all) OH-groups to ester moieties, or to selectively convert, e.g., only the primary hydroxyl functionalities. To achieve the introduction of these sugar segments along the polymer backbone without excessive branching or even cross-linking, a good control over selective ester bond formation is required. As a result, residual functional groups can be left available for further modification, functionalization or cross-linking of the obtained polyester, ideally without the use of tedious protection/de-protection chemistries. Common metalbased and organic catalysts can provide good efficiency in converting alcohol monomers to polyesters even at very low loadings, but the selectivity of such systems for either primary or secondary hydroxyl groups is typically moderate. In contrast, it is well known that enzymes may provide a relatively high selectivity in esterification reactions. The application of enzymes is not limited to their original environment or natural role as such. In fact, their versatility facilitates their use in industrial applications, ranging from the food industry to pharmaceuticals, as well as in organic solvent-based polymerization processes [6].

The most studied enzyme used in polymer synthesis is Candida antarctica lipase $B$ (CALB). This enzyme is responsible for the hydrolysis of fatty esters in nature. In anhydrous media, lipases can be active in the reverse reaction [7] and accept water, alcohols and amines as nucleophiles. By combining di(acyl) donors such as dicarboxylic acids with (di)nucleophiles such as diols, a wide range of polyesters can be produced enzymatically. Moreover, lipases do not require any co-catalyst and they can be used for polycondensation and polytransesterification reactions, ring-opening polymerizations, and polymer modification reactions [8]. For synthetic applications, CALB can be physically adsorbed on the macro-porous resin Lewatit VPOC 1600, consisting of poly(methyl methacrylate-co-butyl methacrylate) [9]. This immobilized enzyme is also known as Novozyme $435^{\circledR}$. Since long chain, apolar alcohols are compounds quite similar to the natural fatty acid substrate, it may be expected that long chain aliphatic monomers are more readily incorporated than polar sugar derivatives [10].

Many polymers have been prepared via one-pot lipasecatalyzed condensation polymerization using a wide range of biobased diols and dicarboxylic acids [11-14]. Especially Gross et al. [9,15-17] have extensively worked with Novozyme $435^{\circledR}$ to synthesize (nearly) linear copolyesters of sorbitol with 1,8-octanediol and adipic acid, while Kobayashi et al. [18] have shown the possibility to prepare polyesters of sorbitol and divinyl sebacate by using CALB as a transesterification catalyst. The strong preference of CALB

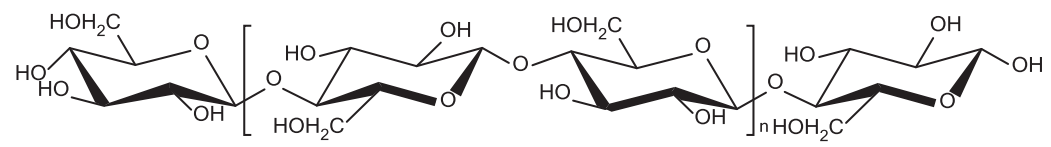

(a) cellulose
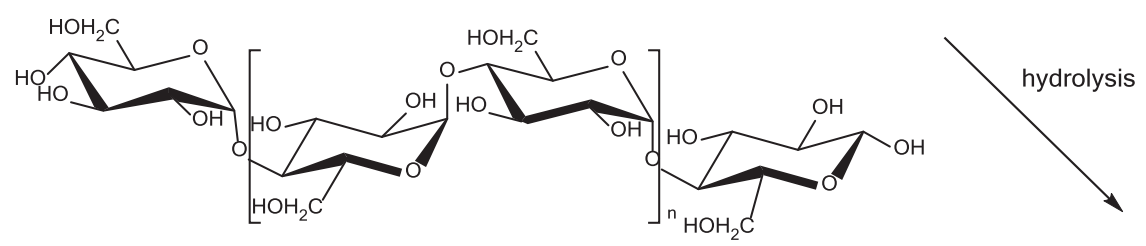

(b) starch

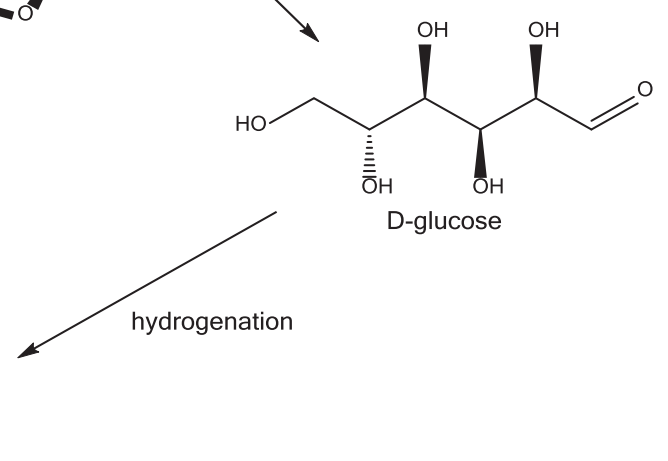

Scheme 1. Production of sorbitol from starch or cellulose. 
for the esterification of primary alcohols over the secondary alcohols is the reason that non-cross-linked, nearly linear polyesters can be obtained with sorbitol as a monomer.

Polyols are commonly used as starting materials for the synthesis of polyurethanes (PU). Polyurethanes are typically prepared by chain extending or cross-linking $\mathrm{OH}-$ functional resins, bearing two or more hydroxyl groups, by the use of di- or polyisocyanates. Trimers of diisocyanates (isocyanurates) are often used to prepare crosslinked PU coating systems. It is well known that those cured products exhibit excellent mechanical and thermal properties [19]. Since the formation of the PU network has to be effective to achieve the targeted final properties, the prepolymer should contain a sufficiently high number of functional groups that will react with the isocyanate curing agent. This can be achieved by either using resins with a relatively low molecular weight or by incorporating monomers bearing additional functional groups. The final formation of a homogenous network leads to an optimal resistance against solvents and usually offers an optimum balance of hardness and flexibility. In recent years, the demand for polyurethanes in the automotive sector, construction, and furniture industries has increased, leading to a rapid growth of polyol production volume which is expected to reach 33.1 billion pounds (lbs.) by 2020 [20]. Furthermore, the development of bio-based polyols will be required to respond to the increasingly strict environmental regulations aimed at developing more sustainable production technologies and to the demand for renewable (polymer) materials on the market. The major polymerproducing companies in Europe are indeed driving investments in polyols from natural oils and/or other renewable compounds [21].

The aim of this work is to synthesize $\mathrm{OH}$-functional polyesters based on sorbitol, and a second renewable diol, with relatively low molecular weights in a controlled way by employing enzymatic polycondensation. These polyesters are synthesized in order to apply them in PU coatings and to optimize the obtained networks upon curing with different isocyanate-based cross-linkers. Special attention was paid to confirming the presence of sorbitol in the polyesters reacted as a 'pseudo-diol' (the two primary alcohols of sorbitol mainly reacting, leaving the majority of the four secondary alcohols as pendant functionalities for postcuring) to obtain mainly linear prepolymers and to quantitatively determine how much sorbitol was actually built into the polyester backbone. The resulting polyesters were examined with different techniques such as: SEC, TGA, DSC, WAXS, NMR, ${ }^{31} \mathrm{P}$ NMR, potentiometric titration, and MALDI-ToF-MS. After the curing of these prepolymers with different polyisocyanate cross-linkers, the resulting polyurethanes were preliminary tested in terms of solvent resistance, hardness and resistance against rapid deformation.

\section{Experimental section}

\subsection{Materials}

Sorbitol was obtained as a gift from Roquette (Neosorb P6 Sorbitol, 98\%, 0.6\% water content as determined via Karl
Fisher titration). 1,8-octanediol (98\%, 1,8-OD), 1,10-decanediol (98\%, 1,10-DD), dimethyl adipate (>99\%), sebacic acid (99\%), dimethyl sebacate (99\%), dodecanedioic acid (99\%), 4,4-dimethylaminopyridine (98\%, DMAP), chromium (III) acetylacetonate $\left(\mathrm{Cr}(\text { acac })_{3}, 99.99 \%\right)$, acetic anhydride, 1-methyl-2-pyrrolidinone(NMP) 2-chloro4,4,5,5-tetramethyldioxaphospholane (95\%) and $0.1-0.5 \mathrm{~N}$ methanolic solution of $\mathrm{KOH}$ were obtained from SigmaAldrich. Adipic acid (99\% HPLC, AA) was purchased from Fluka. Dimethyl suberate ( $>98 \%$ ), dimethyl dodecanedioate (98\%), tetradecanedioic acid (98\%) and dimethyl tetradecanedioate (>96\%) were obtained from TCI. Succinic acid (99+\%) and suberic acid (99\%) were purchased from Acros Organic. Dimethyl succinate (98\%) and dimethyl sebacate (98\%) were obtained from SAFC and Alfa Aesar, respectively. Chloroform-d (99.8\% atom-d), Dimethyl Sulfoxide$\mathrm{d}_{6}$ (DMSO, 99.9\% atom- $d$ ) and Pyridine- $d_{5}$ (99.5\%) were obtained from Cambridge Isotope Laboratories. All solvent were purchased from Biosolve and all chemicals were used as received.

Novozyme $435^{\circledR}$ (Candida antarctica lipase $B$ immobilized on cross-linked polyacrylate beads) was purchased from Novozyme A/S, kept in the fridge at $4{ }^{\circ} \mathrm{C}$ and dried before use following a literature procedure [15].

Dimer fatty acid-based diisocyanate (DDI 1410, 92\% pure, titration value) was kindly provided as a free sample by Cognis (now BASF). Ethyl ester L-lysine diisocyanate (EELDI, 95\% pure) was supplied by Infine Chemicals Co., Limited, China. The isocyanurate trimer of hexamethylene diisocyanate (Desmodur N3600) was a kind gift from Bayer AG. Isophorone diisocyanate (IPDI, 98\% pure Z-/E-stereoisomers +3:1) was purchased from Sigma-Aldrich. All diisocyanates were kept in the refrigerator at $4{ }^{\circ} \mathrm{C}$ under argon.

\subsection{Synthesis of poly(1,8-octanediol-co-sorbitol adipate)}

Polyesters were synthesized using either free dicarboxylic acids or the corresponding dimethyl esters. Here, we describe the synthetic procedure for the dicarboxylic acid-based reactions.

In a typical reaction, adipic acid $(27.09 \mathrm{~g}, 0.154 \mathrm{~mol})$, 1,8-octanediol $(20.68 \mathrm{~g}, 0.139 \mathrm{~mol})$ and sorbitol $(2.83 \mathrm{~g}$, $0.015 \mathrm{~mol}$ ) (diacid: diols $=1: 1$ ) were mixed at $140{ }^{\circ} \mathrm{C}$ in a $300 \mathrm{~mL}$ three neck round bottom flask flange reactor with a magnetically coupled anchor stirrer. The dicarboxylic acid and the corresponding dimethyl ester reactions were conducted in parallel and connected to the same Schlenk line in order to have identical reaction conditions in terms of the inert gas flow during the first stage and the reduced pressure during the second stage of the synthesis. Each reactor was fitted with a vigreux column and a Dean-Stark apparatus to collect the condensate (i.e. either water or methanol). Upon obtaining a homogeneous, ternary mixture at around $140{ }^{\circ} \mathrm{C}$, the reaction temperature was decreased slowly to $90-95^{\circ} \mathrm{C}$ and Novozyme $435^{\circledR}$ (1$10 \mathrm{wt} \%$ with respect to the total amount of monomers) was added to the reaction mixture. During the pre-polymerization step, the mixture was flushed with nitrogen to facilitate the removal of the condensate for $2 \mathrm{~h}$ at which point reduced pressure (from 100 to 53 mbar in 1-2 h) was applied, then the polymerization proceeded at $90{ }^{\circ} \mathrm{C}$ at 
reduced pressure. The reaction was stopped by adding chloroform to the mixture and the product mixture was filtered through a glass filter (pore size 1 ) to separate the obtained dissolved resin from the supported enzyme beads. The crude product was then precipitated in cold methanol, filtered over a glass filter (pore size 4) and isolated as a white powder, which was subsequently dried in vacuo at room temperature overnight.

\subsection{Synthesis of sorbitol-based polyesters based on increasingly apolar dicarboxylic acids}

The polymerization procedure is based on the method described in Section 2.2. In this series, sorbitol (2.24 g, $0.012 \mathrm{~mol}$ ) and 1,10-decanediol (19.45 g, $0.110 \mathrm{~mol}$ ) were chosen as diols while the even-numbered acid/dimethyl ester were varied starting from succinic acid to tetradecanedioic acid by increasing the number of carbon atoms in the diacid molecule in steps of two. To ensure that hydroxyl end-capped polyesters were obtained, the ratio of the monomers was chosen such that an excess of diol was present (unless specified differently). Upon obtaining a homogeneous ternary mixture (varying the temperature between 185 and $140{ }^{\circ} \mathrm{C}$ depending on the monomer combination), the reaction temperature was decreased slowly to $90-116{ }^{\circ} \mathrm{C}$ (unless indicated differently) and Novozyme $435^{\circledR}$ beads ( $10 \mathrm{wt} \%$ with respect to the total monomers amount) was added to the reaction vessel. During the pre-polymerization step, the mixture was flushed with nitrogen to facilitate the removal of the side product for $2 \mathrm{~h}$ at which point reduced pressure (from 100 to $53 \mathrm{mbar}$ in 2-4 h) was applied. The polymerization proceeded at 90-116 ${ }^{\circ} \mathrm{C}$ at reduced pressure (except where indicated differently) during 2-24 h. The reaction was stopped by adding chloroform to the reaction mixture, which was then filtered through a glass filter with pore size 1 to separate the obtained resins from the enzyme. Then the crude product was precipitated in cold methanol, filtered using a glass filter with pore size 4, isolated as a white powder and dried in vacuo at room temperature overnight.

\subsection{Sample preparation for ${ }^{31} P$ NMR spectral analysis}

This analysis was performed according to the procedure reported by Spyros et al. [22] A stock solution was prepared by weighing exactly $520 \mathrm{mg} \mathrm{Cr}(\mathrm{acac})_{3}(29.8 \mu \mathrm{M})$ and $150 \mathrm{mg}$ cyclohexanol $(29.9 \mu \mathrm{M})$ in a $50 \mathrm{~mL}$ volumetric flask. These compounds were subsequently dissolved in a mixture of pyridine and $\mathrm{CDCl}_{3}$ (2.3:1 volume ratio). The stock solution was stabilized and protected from moisture by using silver foil and $4 \AA$ A molecular sieves. Cyclohexanol was used as an internal standard for quantification purposes. Around $40-45 \mathrm{mg}$ of the polymer were accurately weighed into a vial, $500 \mu \mathrm{L}$ of stock solution was added and the solution was transferred to a $5 \mathrm{~mm}$ NMR tube. At that moment, $70 \mu \mathrm{L}$ of phospholane reagent (2-chloro4,4,5,5-tetramethyldioxaphospholane) was added and $\mathrm{HCl}$ gas was formed, indicating that the phosphorylation reaction took place. The reaction mixture was left to react for about $15 \mathrm{~min}$ at room temperature. Upon completion of the reaction, the solution was used to obtain the ${ }^{31} \mathrm{P}$ NMR spectra.

\subsection{Preparation of solvent-borne coatings}

The obtained hydroxy-functional polyesters were cured using the following polyisocyanate curing agents: a trimer of hexamethylene diisocyanate (trade name Desmodur $\mathrm{N} 3600$, NCO equivalent weight $=183 \mathrm{~g} / \mathrm{mol}$ ); IPDI, isophorone diisocyanate (NCO equivalent weight $=111 \mathrm{~g} / \mathrm{mol}$ ); EELDI, ethyl ester L-lysine diisocyanate (NCO equivalent weight $=113 \mathrm{~g} / \mathrm{mol})$; and DDI, dimer fatty acid-based diisocyanate (NCO equivalent weight $=300 \mathrm{~g} / \mathrm{mol}$ ).

$0.3-0.4 \mathrm{~g}$ of polyester were dissolved in $0.3 \mathrm{~mL}$ of solvent and an exact amount of cross-linker, calculated according to the hydroxyl value of the polymer used (between $0.01 \mathrm{~g}$ and $0.2 \mathrm{~g}$ using $0.5-1.1$ equivalents of NCO-groups relative to the $\mathrm{OH}$-groups), was weighed and dissolved in $0.3 \mathrm{~mL}$ of the same solvent. The obtained solutions were mixed together and applied as a wet film onto an aluminum Q-panel (pre-cleaned with ethanol and acetone) by using a doctor blade, targeting a wet film thickness of $160 \mu \mathrm{m}$. When chloroform was used as the solvent, the polyesters and cross-linkers were soluble at room temperature also during the wet coating application. However, most of the coatings applied from chloroform were not satisfactory in terms of their appearance and other solvents such as NMR, acetone, dioxane and dimethylformamide were tested. Due to poor solubility of the polyesters and cross-linkers at room temperature in those solvents, a proper dissolution and mixing of the components as well as the wet coating application had to be carried out at $80-90^{\circ} \mathrm{C}$, which is above the melting temperature of the polyesters. The resulting film was then simultaneously dried and cured at $180{ }^{\circ} \mathrm{C}$ under $\mathrm{N}_{2}$ flow for $30 \min [23]$.

All coatings were tested for hardness, reverse impact resistance and solvent resistance.

\subsection{Characterization}

Size Exclusion Chromatography (SEC) was used to determine both the molecular weight and the molecular weight distribution of the prepolymers. A Waters Alliance set-up equipped with a Waters 2695 separation module, a Waters 2414 differential refractive index detector at $35^{\circ} \mathrm{C}$ and a Waters 2487 dual absorbance detector was used with chloroform as the eluent. The injection volume was $50 \mu \mathrm{L}$. The eluent flow rate was $1.0 \mathrm{~mL} / \mathrm{min}$. Data acquisition and processing was performed using Empower software. Before analysis, each sample was filtered through a $0.2 \mu \mathrm{m}$ PTFE filter. The obtained molecular weights were calculated with respect to polystyrene standards (Polymer Laboratories, $M_{\mathrm{p}}: 580 \mathrm{Da}$ up to $\left.M_{\mathrm{p}}=7.1 \times 10^{6} \mathrm{Da}\right)$.

Thermogravimetric experiments were performed on a TGA Q500 machine and data were analyzed using Universal Analysis 2000 software. A sample of $10 \mathrm{mg}$ was heated from $25^{\circ} \mathrm{C}$ to $600{ }^{\circ} \mathrm{C}$ at a heating rate of $10^{\circ} \mathrm{C} / \mathrm{min}$ under a $\mathrm{N}_{2}$ flow.

The thermal behavior of the polyesters and the derived PU networks were studied by differential scanning calorimetry (DSC) using a TA Instruments Q100 DSC. The heating and cooling rates of the samples were $20^{\circ} \mathrm{C} / \mathrm{min}$ under $\mathrm{N}_{2}$ atmosphere. The Universal Analysis 2000 software was used for data analysis. 
Potentiometric titration was used to determine the acid value (AV) and the hydroxyl value (OHV). The measurements were carried out using a Titrino Plus 848 automatic burette equipped with a Metrohm 801 stirrer and Metrohm silver-titrode.

The AV measurements were carried out by accurately weighing approximately $0.5 \mathrm{~g}$ of polyester after precipitation in methanol, and dissolving the resin in $30 \mathrm{~mL}$ of a mixture of THF (or NMP) and $7 \mathrm{~mL}$ of methanol (4:1 volumetric ratio). Then the solution was titrated using a $0.1 \mathrm{~N}$ methanolic solution of $\mathrm{KOH}$.

The acid value (AV) is defined as the number of milligrams of potassium hydroxide $(\mathrm{KOH})$ required to neutralize $1 \mathrm{~g}$ of polymer resin.

$\mathrm{AV}=\frac{V_{\mathrm{s}} * N * 56.1}{W_{\mathrm{s}}}$

With AV = acid value $(\mathrm{mg} \mathrm{KOH} / \mathrm{g}), V_{\mathrm{s}}=$ volume of methanolic $\mathrm{KOH}$ solution needed to titrate the sample $(\mathrm{mL})$, $N=$ normality of $\mathrm{KOH}$ solution $(\mathrm{mol} / \mathrm{L}), 56.1=$ molar mass of $\mathrm{KOH}(\mathrm{g} / \mathrm{mol})$ and $W_{\mathrm{s}}=$ sample weight $(\mathrm{g})$.

The hydroxyl value (OHV) is the number of milligrams of potassium hydroxide equivalent to the hydroxyl groups present in $1 \mathrm{~g}$ of material. The polyester hydroxyl endgroups were acetylated in solution (THF) with acetic anhydride at room temperature (4-dimethylaminopyridine was used as catalyst), followed by titration of the resulting acetic acid with a normalized $0.5 \mathrm{~N}$ methanolic $\mathrm{KOH}$ solution. All titrations were carried out in duplo.

$\mathrm{OHV}=\mathrm{AV}+\frac{\left(V_{\mathrm{b}}-V_{\mathrm{s}}\right) * N * 56.1}{W_{\mathrm{s}}}$

With $\mathrm{OHV}=$ hydroxyl value $(\mathrm{mg} \mathrm{KOH} / \mathrm{g}), \quad \mathrm{AV}=$ acid value $(\mathrm{mg} \mathrm{KOH} / \mathrm{g}), V_{\mathrm{b}}=$ volume of methanolic $\mathrm{KOH}$ solution needed to titrate the blank $(\mathrm{mL}), V_{\mathrm{s}}=$ volume of methanolic $\mathrm{KOH}$ solution needed to titrate the sample $(\mathrm{mL}), N=$ normality of $\mathrm{KOH}$ solution $(\mathrm{mol} / \mathrm{L}), 56.1=$ molar mass of $\mathrm{KOH}$ $(\mathrm{g} / \mathrm{mol})$ and $W_{\mathrm{s}}=$ sample weight $(\mathrm{g})$.

Matrix assisted laser desorption/ionization time of flight mass spectroscopy (MALDI-ToF-MS) was performed using a PerSeptive Biosystems Voyager-DE STR MALDI-TOF-MS spectrometer equipped with $2 \mathrm{~m}$ flight tubes for linear mode and $3 \mathrm{~m}$ flight tubes for reflector mode and a $337 \mathrm{~nm}$ nitrogen laser ( $3 \mathrm{~ns}$ pulse). All mass spectra were obtained with an accelerating potential of $20 \mathrm{kV}$ in positive ion and reflector mode with delayed extraction. Data were processed with Voyager software. Simulations were performed with in-house developed software. As matrix, 2,4,6-trihydroxyacetophenone (THAP) $(80 \mathrm{mg} / \mathrm{mL}$ THF or methanol) was used and diammonium hydrogen citrate (DAC) (5 mg/mL THF or methanol) was added as cationization agent. The polymer sample was dissolved in THF ( $5 \mathrm{mg} / \mathrm{mL}$ ), to which the matrix material and the ionization agent were added (4:1:4). Subsequently, $0.30 \mu \mathrm{L}$ of this mixture was spotted on the sample plate, and the spots were dried at room temperature.

Carbon nuclear magnetic resonance $\left({ }^{13} \mathrm{C}\right.$ NMR) spectroscopy was performed on a Varian spectrometer at a resonance frequency of $100.64 \mathrm{MHz}$. For the ${ }^{13} \mathrm{C} \mathrm{NMR}$ experiments, the spectral width was $24,155 \mathrm{~Hz}$, the acquisition time was $1.3005 \mathrm{~s}$, the delay time was $3 \mathrm{~s}$ and the number of recorded scans was equal to 35,000 . Samples were prepared by dissolving $40-50 \mathrm{mg}$ of the crude polymer in $0.5 \mathrm{~mL}$ pyridine- $d_{5}$ containing a small amount of $\mathrm{Cr}(\mathrm{acac})_{3}(0.025 \mathrm{M})$ [24] as spin relaxation agent. Chemical shifts are reported in ppm relative to the residual peak of pyridine- $d_{5}(\delta=123.9 \mathrm{ppm})$. Data analysis was performed using Mestrec 4 software.

Phosphor nuclear magnetic resonance $\left({ }^{31} \mathrm{P}\right.$ NMR) spectroscopy was performed on a Bruker spectrometer at a resonance frequency of $161.9756 \mathrm{MHz}$. The spectral width of the experiments was $53569.79 \mathrm{~Hz}$ and the delay time was set at $3 \mathrm{~s}$ with a number of recorded scans of 128 .

$X$-ray diffraction $(X R D)$ measurements were performed on a Rigaku Geigerflex Bragg-Brentano powder diffractometer using $\mathrm{Cu} \mathrm{K} \alpha$ radiation $(\lambda=0.154 \mathrm{~nm})$, at $40 \mathrm{kV}$ and $30 \mathrm{~mA}$. The scans in the $2 \Theta$ range between $10^{\circ}$ and $30^{\circ}$ were performed with a 0.02 step in 2 theta and a dwell time of $1 \mathrm{~s}$. Peak fitting was performed after the subtraction of the background to determine the percentage of crystallinity.

\subsection{Evaluation of cross-linking and coating performance}

The obtained coatings were evaluated using several characterization methods. The solvent resistance of the coatings was assessed through the acetone rub test, in which the sample is rubbed back and forth with a cloth drenched in acetone. If no damage is visible after more than 200 rubs (i.e. 100 'double rubs'), the coating has good acetone resistance. Resistance against rapid deformation was tested using the reverse impact test, performed by dropping a weight of $1 \mathrm{~kg}$ on the back of a coated panel from $79 \mathrm{~cm}$ (ASTM D2794). The coating hardness was measured using the pencil hardness test, performed by scratching the coating with pencils of increasing hardness using a Scratch Hardness Tester model 291 from Erichsen GmbH \& Co KG. The coating thicknesses were measured through magnetic induction using a TQC Layer Thickness Meter (Microprocessor, Coating Thickness Gauge).

\section{Results and discussion}

\subsection{Synthesis of poly(1,8-octanediol-co-sorbitol adipate)}

As is reported in literature, CALB is known to preferably catalyze reactions involving apolar monomers [25]. In contrast, the polymerization of polar monomers by CALB is reported to be more troublesome, which might make the synthesis of (co)polyesters involving sorbitol difficult. Therefore, in order to synthesize polyesters containing sorbitol together with more apolar monomers, a reliable procedure needed to be developed. To study the possibility to prepare sorbitol-containing polymers through CALB catalysis in a controlled manner, a series of polymers containing $5 \mathrm{~mol} \%$ sorbitol (relative to the total amount of monomer, so approx. $10 \mathrm{~mol} \%$ relative to the total amount of diol), 1,8-OD and adipic acid were prepared (Scheme 2).

Table 1 shows the effect of the reaction conditions on the molecular weight distribution and thermal properties of polyesters prepared using adipic acid or its dimethyl ester. Furthermore, the enzyme loading was varied to 
<smiles>OC[C@@H](O)[C@@H](O)[C@H](O)[C@H](O)CO</smiles>

sorbitol<smiles>COC[C@H](O)[C@@H](O)[C@H](O)[C@H](O)COC(C)(C)C</smiles><smiles>[R]OC(=O)CCC(C)C(=O)O[R]</smiles>

diol

$$
\downarrow \begin{aligned}
& \text { Novozyme }{ }^{\circledR} 435,90^{\circ} \mathrm{C}, \text { bulk, } \\
& 24-48 \mathrm{~h}, \text { vacuum }
\end{aligned}
$$

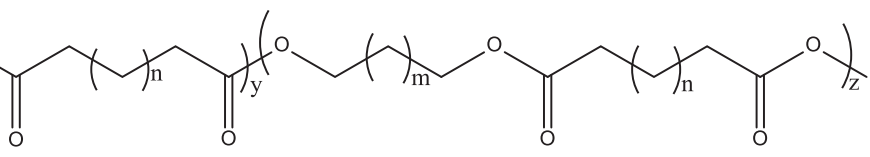

poly(1,8-octanediol- $c o$-sorbitol adipate)

Scheme 2. General reaction scheme of the enzymatic synthesis of sorbitol-based polyesters.

Table 1

Properties of 1,8-octanediol and sorbitol-based polyesters synthesized with different loadings of Novozyme $435^{\circledR}$.

\begin{tabular}{lllllllllll}
\hline Entry & $\mathrm{X}$ & $\mathrm{X}: \mathrm{O}: \mathrm{S}^{\mathrm{a}}$ feed ratio & CALB $(\mathrm{wt} \%)$ & Time $(\mathrm{h})$ & $M_{\mathrm{n}}{ }^{\mathrm{b}}(\mathrm{kg} / \mathrm{mol})$ & $\mathrm{PDI}^{\mathrm{b}}$ & $T_{\mathrm{c}}{ }^{\mathrm{c}}\left({ }^{\circ} \mathrm{C}\right)$ & $T_{\mathrm{g}}{ }^{\mathrm{c}}\left({ }^{\circ} \mathrm{C}\right)$ & $T_{\mathrm{m}}{ }^{\mathrm{c}}\left({ }^{\circ} \mathrm{C}\right)$ & $\Delta H_{\mathrm{m}}{ }^{\mathrm{c}}(\mathrm{J} / \mathrm{g})$ \\
\hline $\mathbf{a}$ & Adipic acid & $1: 09: 0.1$ & $10 \%$ & 46 & 14.2 & 3.3 & 38 & -18 & 60 & 80 \\
b & Adipic acid & $1: 09: 0.1$ & $1 \%$ & 48 & 7.5 & 2.3 & 43 & - & 63 & 96 \\
c & Dimethyl adipate & $1: 09: 0.1$ & $10 \%$ & 26 & 13.3 & 4.6 & 43 & -18 & 61 & 95 \\
d & Dimethyl adipate & $1: 09: 0.1$ & $1 \%$ & 48 & 7.4 & 1.9 & 45 & -26 & 63 & 96 \\
\hline
\end{tabular}

${ }^{a}$ X: dicarboxylic acid or dimethyl ester, O: 1,8-octanediol, S: sorbitol.

${ }^{b}$ Based on SEC measurements on the precipitated polymer.

c Based on DSC measurements, 2nd scan.

investigate its effect on the molecular weight build-up and the polydispersity index (PDI).

As can be seen in Table 1, the amount of CALB used during polymerization affects the molecular weight build-up in time. For example, as is visible for entries $\mathbf{a}$ and $\mathbf{b}$ a molecular weight well above $10 \mathrm{~kg} / \mathrm{mol}$ was obtained within 48 hours of reaction. It should be noted that the molecular weight of entry c could not be improved further after $26 \mathrm{~h}$ of polymerization due to the high viscosity of the reaction mixture. The polymerizations performed with $1 \mathrm{wt} \%$ CALB [26] did not reach such a high molecular weight within the same reaction time. In addition, the measured PDI values are lower than for the reactions using $10 \mathrm{wt} \%$ of CALB, indicating that conversion was lower, as expected. The PDI values of entries $\mathbf{a}$ and $\mathbf{c}$ are significantly higher than the theoretical value of 2 expected for stepgrowth polymerization reactions. This is thought to be mainly due to branching reactions occurring when the secondary $\mathrm{OH}$-groups of sorbitol participate in the polymerization reaction to some extent, which is more pronounced at higher catalyst loadings. For the polymerization using adipic acid in combination with the low enzyme loading (entry b, Table 1), a higher crystalline melting temperature and a larger enthalpy of melting were observed, indicating enhanced crystallization and a better defined crystal structure. To ensure that the reaction times required to prepare these polymers were not excessively long, all subsequent polymerizations were performed using $10 \mathrm{wt} \%$ Novozyme $435^{\circledR}$. Since the loading of CALB in the Novozyme $435^{\circledR}$ preparation is only $10 \mathrm{wt} \%$, the actual amount of CALB used in the reactions is $1 \mathrm{wt} \%$ [27].
When we compare entries $\mathbf{a}$ and $\mathbf{b}$ with entries $\mathbf{c}$ and $\mathbf{d}$ in Table 1, it is clear that there is no significant influence of the use of either the diacid or the dimethyl ester analogue of adipic acid on the molecular weight and PDI of the synthesized polymers. However, during synthesis it was observed that the reactions performed with adipic acid were difficult to control, which is potentially due to slow sublimation of adipic acid and/or 1,8-octanediol occurring on the reactor wall. Sublimation was not observed when using dimethyl adipate. As a result, the yields of the polymerizations of adipic acid, sorbitol and 1,8-octanediol were generally lower than for the reactions performed with the dimethyl adipate.

To determine whether sorbitol is taken up in the polymer backbone during polymerization, a qualitative investigation through nuclear magnetic resonance was performed. Since with a quantitative ${ }^{13} \mathrm{C}$ NMR the assignment of the peaks related to each carbon of the sorbitol unit is not possible, band-selective gradient 2D HSQC (Heteronuclear Single Quantum Coherence) NMR spectroscopy was performed on these samples. Through this experiment it is possible to observe the correlation between the aliphatic carbon and its attached proton $\left({ }^{1} \mathrm{H}\right.$ and $\left.{ }^{13} \mathrm{C}\right)$. Fig. 1 shows the obtained 2D-NMR spectrum of entry $\mathbf{b}$ in Table 1 , between 60 and $74 \mathrm{ppm}$ where the carbon resonances of the sorbitol units are expected. The spectrum was recorded at $125 \mathrm{MHz}$ to improve sensitivity and resolution. Although DMSO- $d_{6}$ is a favorable solvent, the measurement was performed at $60^{\circ} \mathrm{C}$ due to poor solubility of the polymer at room temperature. Based on our assignment, the sorbitol appears to be incorporated along 


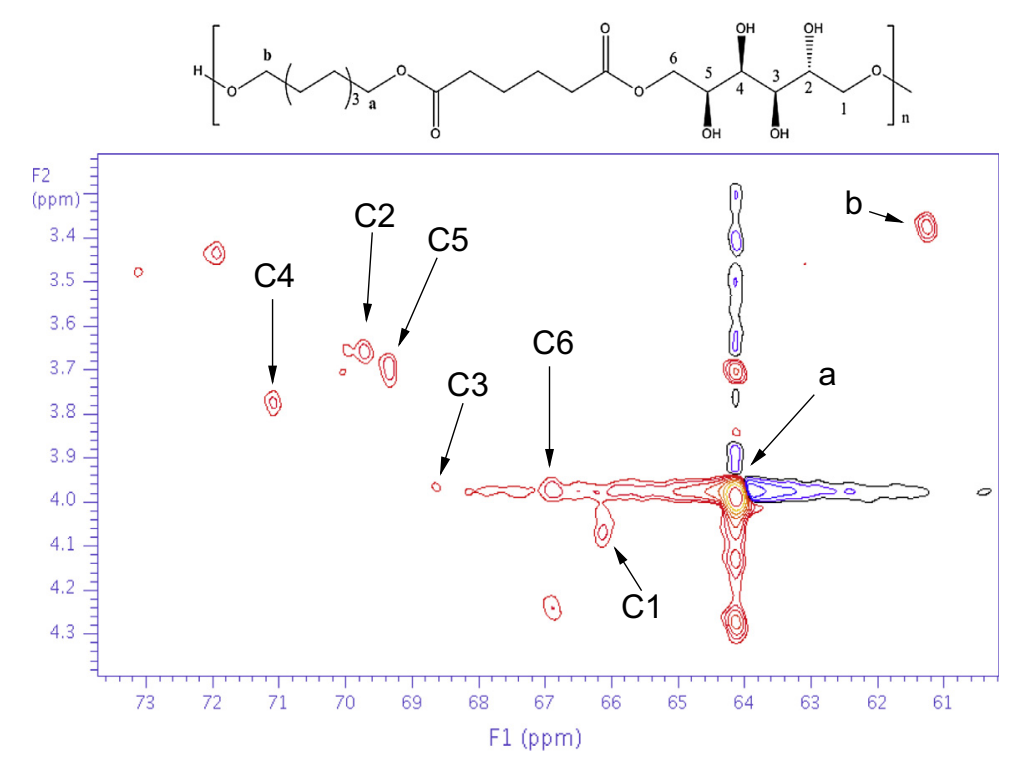

Fig. 1. bs-HSQC of poly(1,8-octanediol-co-sorbitol adipate) (entry b, Table 1 ) recorded in DMSO- $d_{6}$ at $60{ }^{\circ} \mathrm{C}$.

the polyester polymer backbone, which was in fact a benchmark experiment, repeating the work of Gross [9,15-17]. Moreover, several resonances were detected at chemical shifts comparable to those reported by Dordick and Kim [28] regarding analysis of poly(sorbitol adipate).

Thermal analysis of these polymers by DSC showed that melting and crystallization occurred close to $60^{\circ} \mathrm{C}$ and $40{ }^{\circ} \mathrm{C}$, respectively. Furthermore the glass transition temperatures of these polymers lie close to $-20^{\circ} \mathrm{C}$, if detected (note that for semi-crystalline polymers, it is often difficult to observe the glass transition in DSC measurements). These results are in good agreement with observations in literature for comparable polymers [11].

\subsection{Synthesis of sorbitol-based polyesters containing different} dicarboxylic acids/dimethyl esters

In the previous section, we have shown that sorbitol was successfully incorporated into a polymer along with 1,8-octanediol and adipic acid. By using a combination of fully bio-based monomers (sorbitol, 1,10-decanediol and different dicarboxylic acids with an increasing number of carbon atoms in their structure), a series of novel sorbitol-based polyesters was prepared by enzymatic polycondensation. Assuming that the reactive groups present will react exclusively through condensation, the Carothers equation was used to estimate the number average molecular weight expected for a certain composition, assuming that sorbitol reacts as a diol (i.e. the reactivity of the secondary hydroxyl groups is ignored). Obviously, the obtained molecular weight is strongly dependent on the stoichiometric balance of the starting monomers. So, in addition to controlling the obtained molecular weight by tuning the reaction time and/or the enzyme loading as applied for reactions with equal stoichiometry dicarboxylic acids/diesters:diols (entries 1-1a, 2-2a and 6-6a in Tables 2 and 3), the average chain length and type of reactive end-groups can also be controlled by choosing the appropriate stoichiometry (entries 3-3a, 4-4a and 5-5a in Tables 2 and 3). In this way, polyesters with targeted number-average molecular weight $\left(M_{n}\right)$ values from 4 to $6 \mathrm{~kg} / \mathrm{mol}$ were obtained. Targeting a (nearly) linear polyester with pendant hydroxyl group along the backbone chain, this is the appropriate molecular weight range for coating applications, in terms of the number of functional

Table 2

Properties of 1,10-decanediol and sorbitol-based polyesters containing different dimethyl ester residues.

\begin{tabular}{|c|c|c|c|c|c|c|c|c|c|}
\hline Entry & Diester & Initial feed composition $\mathrm{X}: \mathrm{DD}: \mathrm{S}^{\mathrm{a}}$ & Time (h) & Temperature $\left({ }^{\circ} \mathrm{C}\right)$ & $M_{\mathrm{n}}(\mathrm{kg} / \mathrm{mol})^{\mathrm{b}}$ & $\mathrm{PDI}^{\mathrm{b}}$ & $T_{\mathrm{c}}\left({ }^{\circ} \mathrm{C}\right)^{\mathrm{C}}$ & $T_{\mathrm{m}}\left({ }^{\circ} \mathrm{C}\right)^{\mathrm{C}}$ & $\Delta H_{\mathrm{m}}{ }^{\mathrm{c}}(\mathrm{J} / \mathrm{g})$ \\
\hline 1 & Succinic & $1: 0.9: 0.1$ & 24 & 90 & 5.4 & 2 & 48 & 67 & 93 \\
\hline 2 & Adipic & 1:0.9:0.1 & 24 & 95 & 6.8 & 3.4 & 52 & 72 & 100 \\
\hline 3 & Suberic & 1:0.98:0.109 & 9 & 101 & 5.1 & 2.2 & 55 & 75 & 103 \\
\hline 4 & Sebacic & 1:0.99:0.11 & 21 & 90 & 10.2 & 3.5 & 52 & 68 & 106 \\
\hline 5 & Dodecanedioic & 1:0.99:0.11 & 7 & $116^{\mathrm{d}}$ & 8.6 & 2.2 & 54 & 74 & 130 \\
\hline 6 & Tetradecanedioic & $1: 0.9: 0.1$ & 2 & $110^{\mathrm{d}}$ & 6.1 & 2.2 & 63 & 80 & 120 \\
\hline
\end{tabular}

\footnotetext{
a X: dimethyl ester, DD: 1,10-decanediol, S: sorbitol.

b Based on SEC measurements of the precipitated polyester.

c Based on DSC measurements, 2nd scan.

d No processing under reduced pressure.
} 
Table 3

Properties of 1,10-decanediol and sorbitol-based polyesters containing different dicarboxylic acid residues.

\begin{tabular}{|c|c|c|c|c|c|c|c|c|c|}
\hline Entry & Diacid & Initial feed composition $\mathrm{X}: \mathrm{DD}: \mathrm{S}^{\mathrm{a}}$ & Time h & Temperature ${ }^{\circ} \mathrm{C}$ & $M_{\mathrm{n}}(\mathrm{Kg} / \mathrm{mol})^{\mathrm{b}}$ & $\mathrm{PDI}^{\mathrm{b}}$ & $T_{\mathrm{c}}\left({ }^{\circ} \mathrm{C}\right)^{\mathrm{c}}$ & $T_{\mathrm{m}}\left({ }^{\circ} \mathrm{C}\right)^{\mathrm{c}}$ & $\Delta H_{\mathrm{m}}{ }^{\mathrm{c}}(\mathrm{J} / \mathrm{g})$ \\
\hline $1 \mathbf{a}$ & Succinic & 1:0.9:0.1 & 22 & 97 & 7.3 & 3.2 & 46 & 68 & 93 \\
\hline $2 a$ & Adipic & $1: 0.9: 0.1$ & 4 & 105 & 7.5 & 2.8 & 53 & 70 & 100 \\
\hline $3 a$ & Suberic & 1:0.98:0.11 & 8 & 91 & 6.2 & 2.7 & 55 & 75 & 103 \\
\hline $4 a$ & Sebacic & 1:0.99:0.11 & 5 & 93 & 7.3 & 3.8 & 58 & 76 & 106 \\
\hline $5 a$ & Dodecanedioic & 1:0.99:0.11 & 2 & $130^{\mathrm{d}}$ & 3.4 & 8.6 & 54 & 75 & 113 \\
\hline $6 \mathbf{a}$ & Tetradecanedioic & $1: 0.9: 0.1$ & 2 & $110^{\mathrm{d}}$ & 7.7 & 3 & 63 & 80 & 120 \\
\hline
\end{tabular}

a X: dicarboxylic acid, DD: 1,10-decanediol, S: sorbitol.

b Based on SEC measurements of the precipitated polyesters in $\mathrm{MeOH}$.

c Based on DSC measurements, 2nd scan.

d No processing under reduced pressure.

groups present per unit chain length and in terms of the polymer viscosity to assure proper film formation toward cured poly(ester urethane)s with suitable properties. Moreover, one sorbitol unit incorporated into the polyester main chain is already expected to afford a substantial boost to the chain functionality, further facilitating the formation of the PU network when cured with polyisocyanate.

Based on the combination of monomers, the temperature at which the monomers were mixed to form a homogeneous ternary melt was adapted during the solvent-free polymerization. Two factors were taken into account: (1) the lowest temperature suitable to obtain a homogeneous reaction mixture and (2) the potentially limited sorbitol incorporation due to its poor solubility in the apolar reaction system. Initially, the reaction mixture needs to be heated to melt all components and thus to obtain a homogeneous mixture before cooling this mixture to a temperature which is optimal for the enzyme to catalyze the polymerization $\left(70-90^{\circ} \mathrm{C}\right)$. As expected, it was observed that the temperature required to obtain a homogeneous melt depends on the combination of monomers. Especially for reaction mixtures containing relatively high melting, longer chain dicarboxylic acids, e.g. entries 5-5a and 6-6a in Tables 2 and 3, the temperature at which the mixture appeared as a homogeneous melt was not always optimal for the enzyme. In the reactions involving dodecanedioic acid and tetradecanedioic acid and the related dimethyl esters (entries $\mathbf{5}$ and 6-6a in Tables 2 and 3), the reaction mixture had to be kept at $110-116{ }^{\circ} \mathrm{C}$ [29] in order to maintain a clear melt, which is in excess of the temperature (approximately $110^{\circ} \mathrm{C}$ ) at which the enzyme is thought to denature, thereby losing its catalytic activity. The enzyme was added and the temperature was kept the same during the pre-polymerization step ( $2 \mathrm{~h}$ under $\mathrm{N}_{2}$ flow). For entry $\mathbf{5 a}$ in Table 3 , it was possible to obtain an homogeneous mixture only at $130^{\circ} \mathrm{C}$. The polymerization was attempted, anticipating a decrease of the enzyme activity due to denaturation at this high reaction temperature. On the other hand, specifically for the reaction conditions of entry $\mathbf{5 a}$, this high temperature may favor the thermal polymerization of the dodecanedioic acid (which in addition is self-catalyzed), the loss in selectivity of CALB for primary alcohols of the sorbitol unit as well as formation of cycles [30]. These phenomena limit the control of the polymerization to obtain a linear polyester, as is clearly indicated by the high PDI of entry 5a. Moreover, the isolation of the polymer by precipitation in methanol is a step of the procedure aimed at solubilizing the low molecular weight chains and unreacted monomers from the obtained reaction mixture. Due to the apolarity of the longer dicarboxylic acid monomers and the corresponding low molecular weight fraction of the reaction mixture, they will be poorly soluble in a polar solvent such as methanol and may therefore precipitate together with the polymer, which would potentially lead to a reduced average molecular weight and a relatively high PDI value after work-up. This will therefore also affect the final molecular weight distribution detected by SEC. To verify this hypothesis, the precipitation was also performed using an apolar non-solvent, namely hexane. After the precipitation of the more apolar polyester compositions from hexane, the molecular weight distribution indeed appeared to be more narrow compared to the product obtained after precipitation in methanol, as expected.

Another factor to take into account for this particular series of reactions is related to the reduced solubility of sorbitol in the increasingly apolar reaction mixture. It was observed for entries 5-5a and 6-6a in Tables 2 and 3 that, with the decrease of the polarity of the aliphatic comonomers, an homogeneous mixture could no longer be obtained and molten sorbitol was observed as separate droplets residing at the bottom of the reactor. Even if the conditions for these reactions involving apolar comonomers appear quite extreme compared to usual lipase-catalyzed systems, we still obtained polyesters having $M_{\mathrm{n}}$ and yield values in the same range as for the other reactions.

In general, the work up of the reaction mixture upon polymerization is challenging and some aspects need to be improved. During the separation of the enzyme from the obtained polyesters via filtration, the strong effect of inter-chain hydrogen bonding of the polymer was clearly observed. Although the polyester solution in chloroform appeared to be a quite low viscous liquid, the filtration was very difficult and could only be marginally improved by heating the glass filter during filtration. Apparently, chloroform is not the most suitable solvent and the use of a solvent which can limit the hydrogen bonding between chains, such as 1,1,1,3,3,3-hexafluoroisopropanol (HFIP), will help to improve the procedure. In spite of these unfavorable circumstances, the reactions still resulted in a yield between $20 \%$ and $70 \%$, which is comparable to other reported lipase-catalyzed polycondensation reactions [11]. 
The observation of a broad PDI in SEC measurements is obviously related to the hydrodynamic volume of the chains in the particular eluent used based on the standard polymer used for the calibration (in our case polystyrene). As the hydrodynamic volume is strongly influenced by the presence of polymer end-groups as well as the sorbitol $\mathrm{OH}-$ groups, the observed PDI depends on both the mass (i.e. many or few end-groups), the composition (i.e. sorbitol present in the chain or not) of the chains in that particular eluent (chloroform) and possibly on the presence of cycles in the reaction mixture. Since several factors are involved, some discrepancies on the estimation of the molecular weight with other techniques such as NMR and titration can be observed, as discussed in the section below. In view of the foregoing we want to emphasize that the SEC data relative to the used standards merely provides an indication of the obtained molecular weights and facilitates the comparison of similar samples.

\subsection{Molecular characterization of sorbitol-based polyesters containing different dicarboxylic acids/dimethyl esters}

The number-average molecular weight $\left(M_{n}\right)$ of the copolyesters was determined by SEC in chloroform which is calibrated based on polystyrene. In step-growth polymerization, a high molecular weight can be obtained only at a high conversion, which is enhanced by the efficient removal of the condensate. To prepare a linear polyester, strictly bifunctional carboxylic acids and alcohols must be used and according to Carothers equation, a PDI equal to 2 is expected. In our case, sorbitol is considered as a diol but it is in fact a multi-functional component which can lead to some branching if part of the secondary hydroxyl groups reacts. CALB, which has a relatively high selectivity toward primary alcohols, was used in an attempt to prepare mainly linear copolyesters. As the target is to obtain polyesters with a sufficiently high content of reactive end- and side-groups for further modification and/or cross-linking, relatively low molecular weights (between 4000 and $6000 \mathrm{~g} / \mathrm{mol}$ ) were desired. Simultaneously, the moderate molecular weights will favor film formation. The PDI values obtained for the sorbitol-based polyesters in Tables 2 and 3, are mostly close to 2, a value expected for linear step-growth polymers at high conversion. Still, in some other cases (entries 1, 4 and 6, Table 2; entries 2a and 4a Table 3) the PDI values are higher, indicating that some branching may have occurred. Note that the reported PDI values are measured for purified samples, meaning that the crude, as polymerized samples will have broader molecular weight distributions. After all, the dissolution/precipitation method used to purify the samples will result in the removal of a certain low molecular weight fraction of the product mixture. The presence of cycles is another factor that affects the molecular weight distribution: bulk polymerization in the melt typically leads to high reaction mixture viscosities, which may favor cycle formation [30]. These cyclic chains can be formed either by a direct esterification of the end-groups of the same chain or through transesterification of an $\mathrm{OH}$-end group with an ester group present in the same chain ("back-biting") [30].
The detection and quantification of the sorbitol units and their $\mathrm{OH}$-groups present in the polyester chains is of great importance. It would facilitate the determination of the amount of sorbitol actually built into the polymer backbone, provide information regarding the degree of selectivity of CALB for the primary vs. the secondary hydroxyl groups and serve as a quantitative determination of the amount of $\mathrm{OH}$-end groups (a value which is of utmost importance for curing purposes). Those are important steps on the way to complete the molecular characterization with the aim to analyze the content and the position of sorbitol in the polymers.

Through inverse-gated decoupling ${ }^{13} \mathrm{C}$ NMR (Fig. 2), the signal related to end-groups of the polymer (entry $\mathbf{b}$, Table 1) was used to calculate the $M_{n}$ of the final polyol. It appears that the $M_{\mathrm{n}}$ calculated by NMR is around $4.5 \mathrm{~kg} / \mathrm{mol}$ which is low compared to the value determined by SEC $(7.5 \mathrm{~kg} / \mathrm{mol})$. Thus, in accordance with this observation regarding an overestimation of the molecular weight based on SEC data compared to NMR data (which may be very well due to the use of PS standards, having hydrodynamic volumes strongly deviating from those of our polyesters), it was decided to target slightly higher molecular weights in terms of the SEC results. Moreover, it was possible to calculate the $\mathrm{mol} \%$ of sorbitol incorporated after polymerization. In Table 4 , the data regarding the sorbitol quantification, comparing the initial feed with the actually incorporated amount based on inverse gated decoupling ${ }^{13} \mathrm{C}$ NMR measurements, are summarized. In general, it appears that approximately $5-53 \mathrm{~mol} \%$ of the initially present sorbitol is incorporated into the polyester backbone, depending on the reaction mixture and conditions. It can be seen in Table 4 how e.g. the extreme reaction conditions for the polymerization (entry 5a, Table 3) and the use of tetradecanedioic acid (entry 6a, Table 3 ) effect the amount of sorbitol incorporated into the polymer: entry 5a only contains a very low amount ( $5 \mathrm{~mol} \%$ ) of sorbitol. On the other hand, even if polarity differences between the monomers (e.g. entry $\mathbf{6 a}$, Table 3 ) appear to be unfavorable for the implementation of sorbitol, it shows that the incorporation was still rather successful, with $40 \mathrm{~mol} \%$ of the fed sorbitol ending up in the purified polymer product. In general, it is observed that not more than $53 \mathrm{~mol} \%$ (entry 2a, Table 4) of the feed sorbitol was incorporated into the copolyesters at the applied reaction conditions. It should be noted here that, as sorbitol is not the favored substrate for CALB compared to the significantly more apolar 1,10-decanediol, its incorporation occurs at a lower rate throughout the polymerization. This can be quite clearly seen for entry $\mathbf{1}$ in Table 4 , where the PDI is indicating a conversion around $60-70 \%$. This means that, most likely, a relatively high fraction of the sorbitol feed is still present in monomeric or oligomeric form when the polymerization is stopped. In addition, these low molecular weight species may be rather soluble in methanol, which may lead to a disproportionate removal of sorbitol and sorbitol-containing oligomeric species. The observed fluctuations in the amount of sorbitol built into the polyesters for the different compositions is not well understood at this moment. 
(a)

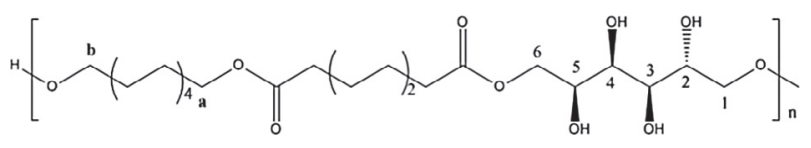

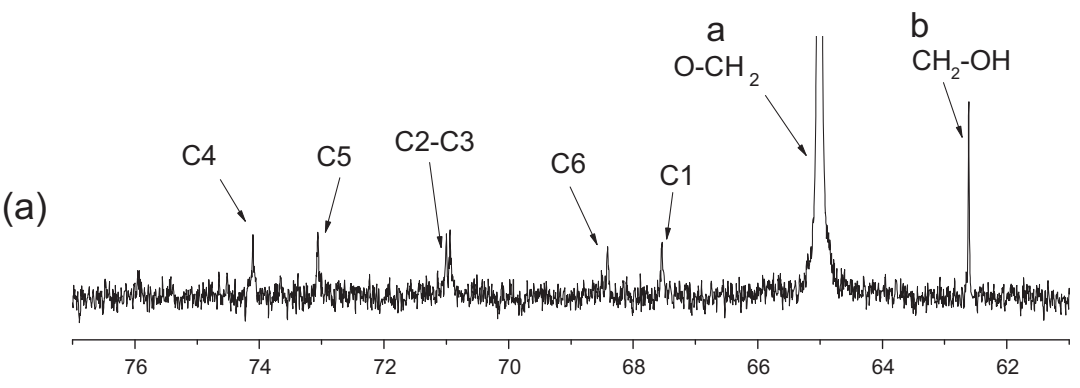

(b)

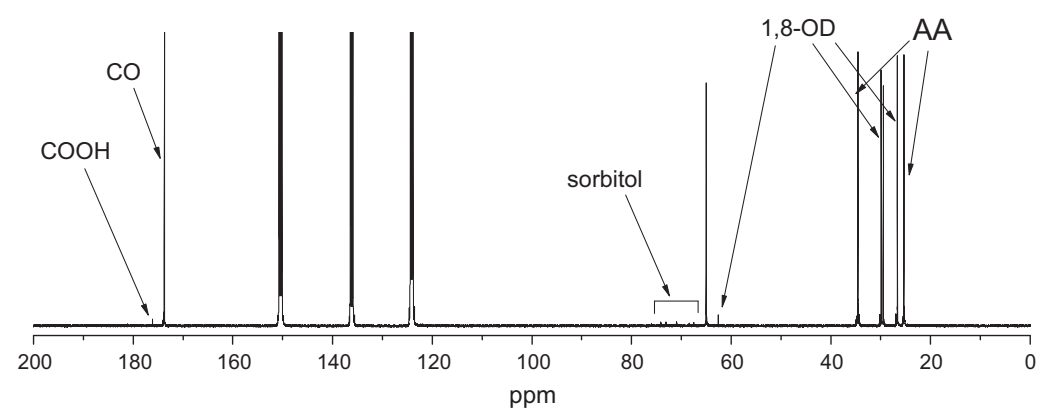

Fig. 2. Inverse-gated decoupling ${ }^{13} \mathrm{C}$ NMR spectrum of poly(1,8-octanediol-co-sorbitol adipate) (entry b, Table 1$)$ recorded in pyridine- $d_{5}$.

Table 4

Feed ratio and final composition of sorbitol-containing polyesters, measured by inverse-gated decoupling ${ }^{13} \mathrm{C}$ NMR spectroscopy.

\begin{tabular}{|c|c|c|c|c|c|c|c|c|}
\hline \multirow[t]{2}{*}{ Entry } & \multirow[t]{2}{*}{ Monomers } & \multirow{2}{*}{$\begin{array}{l}\text { Initial feed } \\
\text { composition } \\
X: D i o l: S\end{array}$} & \multirow{2}{*}{$\begin{array}{l}\text { Sorbitol feed } \\
\text { composition (mol\%) }\end{array}$} & \multirow{2}{*}{$\begin{array}{l}\text { Polymer sorbitol content } \\
{ }^{13} \mathrm{C} \mathrm{NMR}^{\mathrm{a}}(\mathrm{mol} \%)\end{array}$} & \multirow{2}{*}{$\begin{array}{l}\text { Sorbitol } \\
\text { incorporated } \\
(\%)\end{array}$} & \multirow{2}{*}{$\begin{array}{l}{ }^{13} \mathrm{C} \\
\mathrm{NMR} \\
M_{\mathrm{n}}(\mathrm{kg} / \\
\mathrm{mol})^{\mathrm{b}}\end{array}$} & \multicolumn{2}{|l|}{ SEC } \\
\hline & & & & & & & $\begin{array}{l}M_{\mathrm{n}}(\mathrm{kg} / \\
\mathrm{mol})^{\mathrm{c}}\end{array}$ & PDI \\
\hline b & $\begin{array}{l}\text { Adipic acid + sorbitol + } \\
1,8-\text { OD }\end{array}$ & 1:0.9:0.1 & 5.0 & 2.47 & 49 & 5.3 & 7.5 & 2.3 \\
\hline $1 a$ & $\begin{array}{l}\text { Succinic acid + sorbitol + } \\
1,10-\text { DD }\end{array}$ & 1:0.9:0.1 & 5.1 & 1.18 & 23 & 5.7 & 7.3 & 3.2 \\
\hline 1 & $\begin{array}{l}\text { Dimethyl succinate + } \\
\text { sorbitol + } 1,10-\text { DD }\end{array}$ & 1:0.9:0.1 & 4.7 & 1.09 & 23 & 5.3 & 6.1 & 1.6 \\
\hline $2 a$ & $\begin{array}{l}\text { Adipic acid + sorbitol + } \\
\text { 1,10-DD }\end{array}$ & 1:0.9:0.1 & 4.7 & 2.47 & 53 & 4.0 & 7.5 & 2.8 \\
\hline 3a & $\begin{array}{l}\text { Suberic acid + sorbitol + } \\
1,10 \text {-DD }\end{array}$ & 1:0.98:0.109 & 5.2 & 0.25 & 5 & 4.8 & 6.2 & 2.7 \\
\hline $7 a$ & $\begin{array}{l}\text { Tetradecanedioic acid + } \\
\text { Sorbitol + 1,10-DD }\end{array}$ & 1:0.9:0.1 & 5.0 & 2.00 & 40 & 12.0 & 7.27 & 3 \\
\hline
\end{tabular}

$\mathrm{S}=$ sorbitol.

a Assuming that all secondary alcohols of the sorbitol unit are not esterified.

${ }^{b}$ Based on the ${ }^{13} \mathrm{C}$ NMR area of diol end-group not reacted present in the polyesters after precipitation in $\mathrm{MeOH}$.

c Based on SEC measurements of the precipitated polyesters.

\subsubsection{Polymer functionality: determination of the sorbitol} content

Several techniques were used to arrive at a quantitative assessment of the sorbitol content of the different polyesters described in this paper.

3.3.1.1. Potentiometric titration. Due to the presence of vicinal secondary hydroxyl groups on the sorbitol unit, it was necessary to verify whether the acetic anhydridebased $\mathrm{OH}$-titration method, which involves the acetylation of all $\mathrm{OH}$-groups in a polymer sample [31], was an accurate technique to determine the $\mathrm{OH}$-content of these samples. It was found that virtually all $\mathrm{OH}$-groups which should be present in a known amount of sorbitol were accounted for, meaning that steric factors did not significantly hinder the full acetylation of the sorbitol monomer. The 
Table 5

Sorbitol-based $\mathrm{OH}-$ functional polyesters: potentiometric titration and ${ }^{31} \mathrm{P}$ NMR spectroscopy results.

\begin{tabular}{|c|c|c|c|c|c|c|c|c|}
\hline \multirow[b]{2}{*}{ Resin } & \multirow[b]{2}{*}{ Monomers } & \multirow[b]{2}{*}{$\begin{array}{l}\text { Initial fee composition } \\
\mathrm{X} \text { :Diol:S }\end{array}$} & \multicolumn{2}{|l|}{ SEC } & \multicolumn{2}{|c|}{ Potentiometric titration } & \multicolumn{2}{|l|}{${ }^{31} \mathrm{P}$ NMR } \\
\hline & & & $\begin{array}{l}M_{\mathrm{n}}(\mathrm{kg} / \\
\mathrm{mol})^{\mathrm{a}}\end{array}$ & PDI & $\begin{array}{l}\text { AV } \\
(\mathrm{mg} \mathrm{KOH} / \\
\mathrm{g})^{\mathrm{b}}\end{array}$ & $\begin{array}{l}\mathrm{OHV}(\mathrm{mg} \\
\mathrm{KOH} / \mathrm{g})^{\mathrm{b}}\end{array}$ & $\begin{array}{l}\mathrm{AV}(\mathrm{mg} \\
\mathrm{KOH} / \mathrm{g})^{\mathrm{C}}\end{array}$ & $\begin{array}{l}\mathrm{OHV}(\mathrm{mg} \\
\mathrm{KOH} / \mathrm{g})^{\mathrm{c}}\end{array}$ \\
\hline b & $\begin{array}{l}\text { Adipic acid + sorbitol + } \\
\text { 1,8-octanediol }\end{array}$ & $1: 0.9: 0.1$ & 7.5 & 2.3 & 11.4 & 80.3 & 9.9 & 64.2 \\
\hline $1 \mathbf{a}$ & $\begin{array}{l}\text { Succinic acid + sorbitol + } \\
\text { 1,10-decanediol }\end{array}$ & $1: 0.9: 0.1$ & 7.3 & 3.2 & 9.8 & 56.5 & 8.2 & 62.5 \\
\hline 1 & $\begin{array}{l}\text { Dimethyl succinate }+ \text { sorbitol }+ \\
\text { 1,10-decanediol }\end{array}$ & $1: 0.9: 0.1$ & 6.1 & 1.6 & 3.6 & 87.3 & 2.3 & 67.6 \\
\hline $2 \mathbf{a}$ & $\begin{array}{l}\text { Adipic acid + sorbitol + } \\
\text { 1,10-decanediol }\end{array}$ & $1: 0.9: 0.1$ & 7.5 & 2.8 & 5.7 & 42.4 & 5.7 & 57.6 \\
\hline $3 a$ & $\begin{array}{l}\text { Suberic acid + sorbitol + } \\
\text { 1,10-decanediol }\end{array}$ & 1:0.98:0.109 & 6.2 & 2.7 & - & - & 8.5 & 42.1 \\
\hline $7 \mathbf{a}$ & $\begin{array}{l}\text { Tetradecanedioic acid + } \\
\text { sorbitol }+1,10 \text {-decanediol }\end{array}$ & $1: 1$ & 7.7 & 3 & - & $37.5^{d}$ & 11.2 & 42.5 \\
\hline
\end{tabular}

$\mathrm{S}=$ sorbitol.

a Data obtained by SEC.

b Data obtained by potentiometric titration after precipitation in $\mathrm{MeOH}$.

c Data obtained by ${ }^{31} \mathrm{P}$ NMR after precipitation in $\mathrm{MeOH}$.

d Solution of THF with $30 \% \mathrm{v} / \mathrm{v}$ pyridine, poor solubility.

acetylation time for compounds bearing primary as well as secondary $\mathrm{OH}$-groups was extended from 15 to $50 \mathrm{~min}$. It will ensure that also less reactive, sterically crowded $\mathrm{OH}$-groups are fully acetylated.

As mentioned before, some polymerizations were conducted using a ratio of dicarboxylic acid:diols $=1: 1$ (considering sorbitol as a diol) meaning that, on average, chains should have one hydroxyl and one carboxylic acid end-group, leading to similar acid and hydroxyl values. As can be seen in Table 5, the hydroxyl values are significantly higher than the acid values, which is thought to be a first indication of the presence of the sorbitol in the polyester. The resins reported have different $M_{\mathrm{n}}$ values and they have been synthesized from different monomers, which should have an impact on the $\mathrm{COOH}$ and $\mathrm{OH}$ values detected. This is indeed the case: samples for which SEC indicates a high $M_{\mathrm{n}}$ show less end-groups compared to their low $M_{\mathrm{n}}$ counterparts, and reactions in which the dimethyl esters were used show low AV compared to the corresponding reaction using the dicarboxylic acid monomer. The low AV values, detected when the dimethyl esters were used, indicate that some hydrolysis of the methyl ester groups occurs during the polymerization. Since the solubility of the polyesters containing dicarboxylic acid units longer than C8 was very poor in THF or NMP, the determination of the $\mathrm{OHV}$ and $\mathrm{AV}$ via potentiometric titration could not be performed. Other potentiometric titration methods using pyridine as a solvent, which is harmful and difficult to dispose [32,33] in the amount required for the measurements, were not considered. Therefore the use of ${ }^{31} \mathrm{P}$ NMR as an alternative analytical method was envisaged.

3.3.1.2. ${ }^{31} P$ NMR. The identification of the different sorbitol-derived products and quantification of e.g. the extent of esterification of primary vs. secondary OH-groups was targeted. Here, a short description of the method is provided [22]: the phospholane reagent (2-chloro-4,4,5,5tetramethyldioxaphospholane) reacts with primary and secondary hydroxyl groups as well as with carboxylic acid groups (Scheme 3). Since the NMR technique is based on differences in electronic environment, similar functional groups such as the sorbitol primary and secondary hydroxyl groups after phosphorylation appear in the ${ }^{31} \mathrm{P}$ NMR spectrum at a different chemical shift. They can be identified, giving information concerning the ratio between primary and secondary alcohols present in the studied polyesters. Thanks to this discrimination, more information is accessible to distinguish between primary and secondary hydroxyl groups of the different monomers and to give an estimation of their relative degree of reaction. In addition, free carboxylic acid groups can be identified as well at $134.6-135 \mathrm{ppm}$. The use of an internal standard, such as cyclohexanol giving a signal at $145.06 \mathrm{ppm}$,

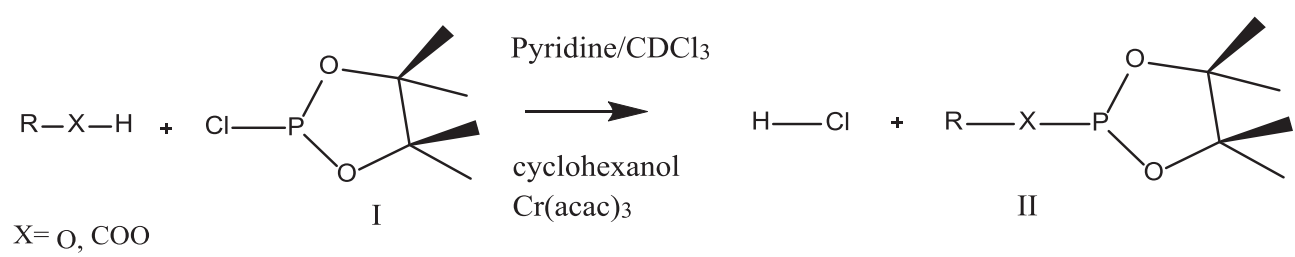

Scheme 3. Phosphorylation reaction of hydroxyl and carboxylic acid group with 2-chloro-4,4,5,5-tetramethyldioxaphospholane (I) and the related derived product (II). 
facilitates the quantification of the various species through the appropriate integration. The presence of the peak at 174.95 ppm, points to unreacted phospholane compound. Although it is claimed in literature that all functional groups react with the phospholane compound [34,35], we cannot be absolutely sure that this is the case with the sterically hindered sorbitol residues incorporated in the polymer chains. We found evidence that all the $\mathrm{OH}$ groups of the sorbitol monomer have reacted with the phospholane compound. However, we cannot be sure that this is also the case for the sorbitol incorporated into the polyester chains. Another characteristic peak is assigned to the product of the phospholane compound upon reaction with moisture, normally used as a reference chemical shift at $132.20 \mathrm{ppm}$. Another peak is detected at $140.6 \mathrm{ppm}$ and is related to a phenol compound which is thought to be present as an impurity in sorbitol.

The assignment of the peaks related to the phospholane compound reacted with primary $\mathrm{OH}$ groups and secondary $\mathrm{OH}$ groups was possible through ${ }^{1} \mathrm{H}$-coupled measurements. The signals related to primary $\mathrm{OH}$-groups appear as triplets while the signals from secondary OH-groups appear as doublets. For a precise quantification, the integrations were performed using the data of decoupled experiments. An example of a representative ${ }^{31} \mathrm{P}$ NMR spectrum and the related assignment is shown in Fig. 3. Based on the assignment from Spyros, for the regions where primary and secondary alcohols are detected [22], it has been observed that in our case those regions are inverted.

Compared to the ordinary titration methods, the ${ }^{31} \mathrm{P}$ NMR spectroscopy technique is highly attractive for several reasons [22]: the amount of sample required is low (milligrams instead of the grams required for titration), the quantification of both carboxylic acid and hydroxyl groups is possible with one and the same experiment, and the time required for each measurement is shorter compared to potentiometric titration. Moreover, in our case the improved solubility of the polymers observed in pyridine- $d_{5}$ allows the measurement of OHV and AV values by NMR also for samples which are not soluble in the conventional solvents used for potentiometric titration.

Looking at the ${ }^{31} \mathrm{P}$ NMR data (Table 6), the AVs look quite similar to the potentiometric titration values (please compare data presented in Table 5), whereas the OHVs determined by NMR are lower than the OHVs derived from potentiometric titrations. Since the phospholane compound used to derivatize the hydroxyl groups is quite bulky, full conversion of the different sorbitol OH-groups may not be achieved for steric reasons, leading to deviating results. However, the assignment of primary and secondary sorbitol OH-groups was achieved as well as their potential quantification based on the internal standard. In Table 6, the OHV and AV measured through ${ }^{31} \mathrm{P}$ NMR are expressed in $\mathrm{mg} \mathrm{KOH} / \mathrm{g}$ to facilitate comparison with the titration results given in Table 5 . From this analysis, it is possible to observe the ratio between unreacted primary and secondary $\mathrm{OH}$-groups of the sorbitol unit. If sorbitol is incorporated as a diol residue in the linear polyester chain (i.e. only the two primary $\mathrm{OH}$-groups have reacted), the ratio between the two species would be secondary $\mathrm{OH}$ : primary $\mathrm{OH}=4: 0$ while if the sorbitol would be at the end of the chain, the ratio would be $4: 1$. All the other combinations where sorbitol reacts as a polyol (i.e. not only the primary but also part of the secondary $\mathrm{OH}$-groups have been esterified) will give a ratio less than 4 . From Table 6, only two cases, viz. entries $\mathbf{1}$ and 3a, are observed where the ratio is below 4 , for the other samples this ratio appears higher. It must be highlighted that, even when the
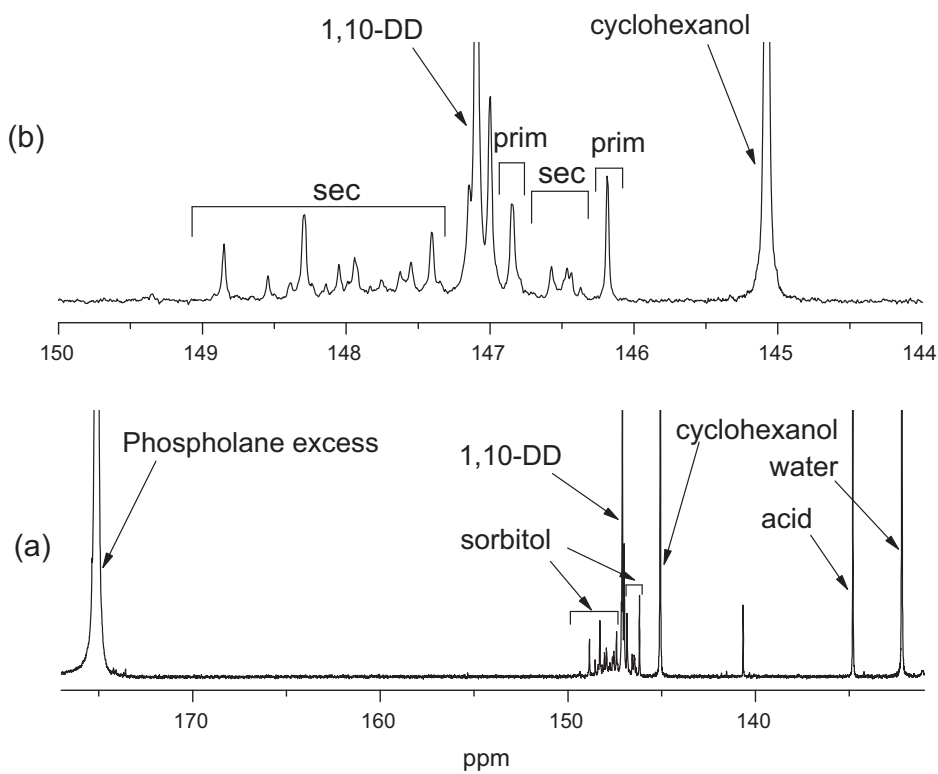

Fig. 3. ${ }^{31} \mathrm{P}$ NMR spectrum of poly(1,10-decanediol-co-sorbitol suberate) (entry 3a, Table 3): (a) schematic representation of a typical spectrum including assignment of the most relevant peaks. (b) Zoom of the region between 145 and 150 ppm with assignment for primary alcohol (prim), secondary alcohol $(\mathrm{sec})$ of sorbitol and primary alcohol as end-group from 1,10-decanediol (1,10-DD). 
Table 6

Quantitative results of hydroxyl and carboxylic groups distribution in sorbitol-based polyesters via ${ }^{31} \mathrm{P}$ NMR spectroscopy, (S = sorbitol).

\begin{tabular}{|c|c|c|c|c|c|c|c|c|}
\hline Resin & Monomers & $\begin{array}{l}\text { Initial fee } \\
\text { composition } \\
\text { X:Diol:S }\end{array}$ & $\begin{array}{l}\text { OH primary } \\
(\mathrm{mg} \mathrm{KOH} / \mathrm{g})\end{array}$ & $\begin{array}{l}\text { OH secondary } \\
(\mathrm{mg} \mathrm{KOH} / \mathrm{g})\end{array}$ & $\begin{array}{l}\text { OH diol } \\
(\mathrm{mg} \mathrm{KOH} / \\
\mathrm{g})\end{array}$ & $\begin{array}{l}\text { OH total } \\
(\mathrm{mg} \mathrm{KOH} / \\
\mathrm{g})\end{array}$ & $\begin{array}{l}\mathrm{AV}(\mathrm{mg} \\
\mathrm{KOH} / \mathrm{g})\end{array}$ & $\begin{array}{l}\text { Ratio } \\
\text { secondary:primary } \\
\text { OH of sorbitol }\end{array}$ \\
\hline $\mathbf{b}$ & $\begin{array}{l}\text { Adipic acid + sorbitol + } \\
\text { 1,8-octanediol }\end{array}$ & 1:0.9:0.1 & 3.2 & 35.5 & 15.8 & 54.4 & 9.9 & 11.1 \\
\hline 1a & $\begin{array}{l}\text { Succinic acid + sorbitol + } \\
\text { 1,10-decanediol }\end{array}$ & 1:0.9:0.1 & 1.8 & 37.6 & 14.9 & 54.3 & 8.2 & 20.1 \\
\hline 1 & $\begin{array}{l}\text { Dimethyl } \\
\text { succinate + sorbitol + } \\
1,10 \text {-decanediol }\end{array}$ & 1:0.9:0.1 & 10.6 & 37.8 & 16.8 & 65.3 & 2.3 & 3.6 \\
\hline $\mathbf{2 a}$ & $\begin{array}{l}\text { Adipic acid + sorbitol + } \\
\text { 1,10-decanediol }\end{array}$ & 1:0.9:0.1 & 2.5 & 33.1 & 16.3 & 51.9 & 5.7 & 13.2 \\
\hline $3 a$ & $\begin{array}{l}\text { Suberic acid + sorbitol + } \\
1,10 \text {-decanediol }\end{array}$ & 1:0.98:0.109 & 4.5 & 15.6 & 13.5 & 33.6 & 8.5 & 3.5 \\
\hline $7 a$ & $\begin{array}{l}\text { Tetradecanedioic } \\
\text { acid + sorbitol + 1,10- } \\
\text { decanediol }\end{array}$ & 1:0.9:0.1 & 1.9 & 20.1 & 9.2 & 31.3 & 11.2 & 10.6 \\
\hline
\end{tabular}

reaction conditions are quite far from the optimum (for example entry 7a, Table 6 where tetradecanedioic acid was used), still sorbitol appears to be incorporated into the polymer chain predominantly as a diol.

3.3.1.3. MALDI-ToF-MS. MALDI-ToF-MS was used to analyze the distribution of the monomer residues over the chains. Although it is known that this technique cannot be used to derive values for $M_{\mathrm{n}}$ or give quantitative information concerning the amounts of certain observed species, through this analysis it is possible to observe the composition of the single chains. In this way, more information becomes available concerning the end-group structure of each polyester sample. Furthermore, one can acquire evidence if sorbitol is incorporated into the polymer chains or not. An example of a representative MALDI-ToF-MS spectrum is shown in Fig. 4.

Four main distributions are detected. Distributions 1 and 2 are assigned to macromolecules which do not contain sorbitol: the most intense distribution (D1) is assigned to chains with an increasing number of repeat units of the adipic acid/1,8-octanediol type ranging from 3 to 9 , end-

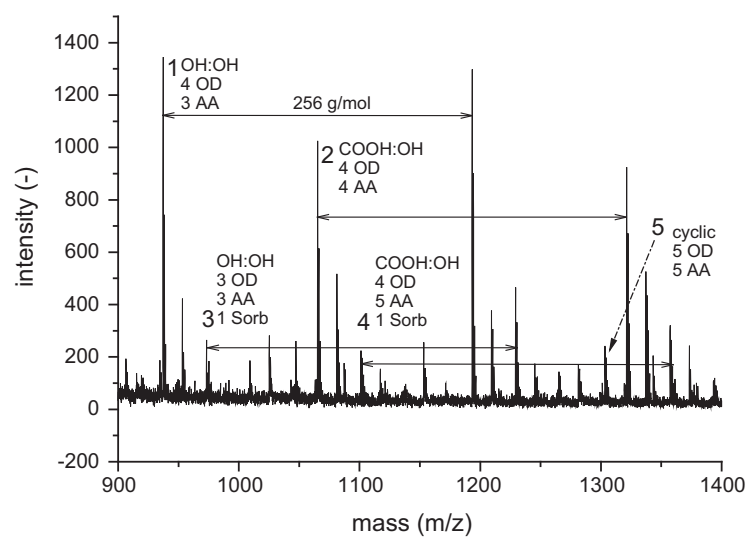

Fig. 4. Section of the MALDI-ToF-MS spectra of poly(1,8-octanediol-cosorbitol adipate) (entry b, Table 1). End-groups belonging to the several distribution are indicated in the figure. capped with an additional diol residue, whereas the second one (D2) shows repeat units of adipic acid and 1,8-octanediol as well, but with equal numbers of adipic acid and 1,8 -octanediol residues present (resulting in the $\mathrm{OH}$ and one $\mathrm{COOH}$ end group). The other two distributions (D3 and D4) do contain sorbitol and we can distinguish a distribution with two OH-end groups (D3) as well as a distribution having a carboxylic acid and an hydroxyl endgroup (D4). Only in one case a single peak has been found related to a composition of an acid end-capped chain with a sorbitol unit present (entry 7a, Table 3). This means that sorbitol is incorporated inside the polymer backbone.

The situation is quite similar when dimethyl esters were used instead of dicarboxylic acids: the most important distributions consist of repeat units of diester/1,10decanediol (as for D1 and D2 of the previous example). In addition to these distributions, distributions are observed where sorbitol is present and the chains are either endcapped with a diol or a diester residue (as for D3 and D4 of the previous example). In all measured samples, some cyclic structures having between 3 and 5 repeat units were detected too (e.g. D5 in Fig. 4).

Overall, the polymer chains appear to be predominantly hydroxyl functionalized, even if some carboxylic acid endgroups are also present.

Hydrolytic cleavage caused by water can strongly affect the control of the polymer structure and influence the endgroup structure [36,37]. In case diesters are used as acyl donors, these competitive reactions caused by water can result in polymer chains with more carboxylic acid endgroups than expected [38]. This is in accordance with the potentiometric titration results which show an AV for some of the reactions where the dimethyl ester was used. Additionally, when methanol is the formed condensate, it was observed that it causes a deactivation of the enzyme by binding of methanol to the substrate binding site [39]. For those reasons the concentration of the condensates (water and methanol in our case) needs to be reduced as much as possible to favor a controlled polymer synthesis.

According to literature, one can distinguish different sources of water with respect to immobilized enzymes [40]. A drying method should remove most of the free 
and loosely bound water without depleting the crystallization water from the tridimensional structure of the enzyme, which would deactivate it [41]. Following a literature report, Novozyme $435^{\circledR}$ was dried under reduced pressure (10 mbar) at $25^{\circ} \mathrm{C}$ for $24 \mathrm{~h} \mathrm{[15]}$.

\subsubsection{Thermal analysis of the sorbitol-based polyesters} containing different dicarboxylic acids/dimethyl esters

Differential scanning calorimetry (DSC) analysis shows that all samples are semi-crystalline and this is the reason why the glass transition temperature $\left(T_{\mathrm{g}}\right)$ could not always be determined. In the few cases where a $T_{\mathrm{g}}$ was observed, it was found to be around $-18^{\circ} \mathrm{C}$, as generally expected for this type of aliphatic polyesters [6].

From Tables 2 and 3 we can clearly see the increase of the melting temperature and the enthalpy following the increase of the number of carbons of the dicarboxylic acid residue.

Thermogravimetric analysis (TGA) of the copolyesters prepared in this study was performed. The study of thermal degradation and thermal stability is of great importance in terms of processing, application and more in general for the development of a safe material [42]. The TGA curves depicted in Fig. 5 show onset of decomposition values of the polymers between 350 and $380^{\circ} \mathrm{C}$, indicating thermal stability up to high temperature, certainly significantly higher than their melting points.

\subsection{Curing and coating evaluation of sorbitol-based polyesters}

The presented biobased polyesters display $M_{\mathrm{n}}$ and functional groups in a range appropriate for coating

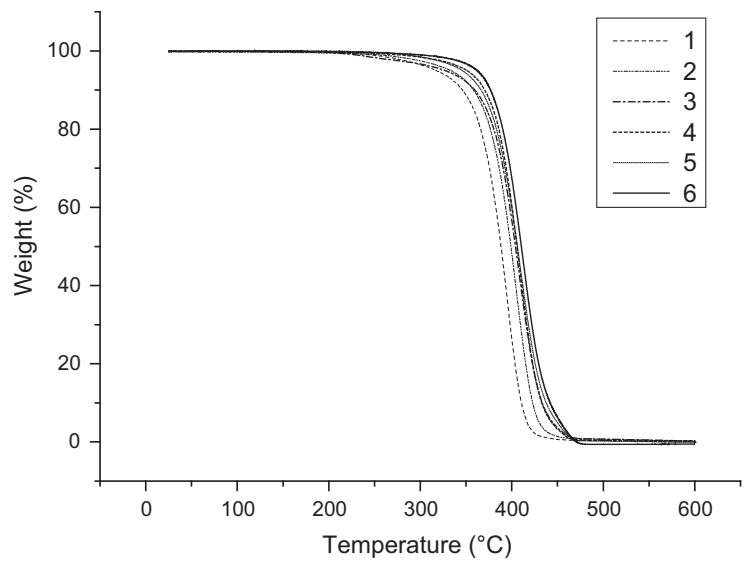

Fig. 5. TGA thermograms obtained for the synthesized (co)polymers listed in Table 3, i.e.: (1) poly(1,10-decanediol-co-sorbitol succinate), (2) poly(1,10-decanediol-co-sorbitol adipate), (3) poly(1,10-decanediol-cosorbitol suberate), (4) poly(1,10-decanediol-co-sorbitol sebacate), (5) poly(1,10-decanediol-co-sorbitol dodecanedioate) and (6) poly(1,10-decanediol-co-sorbitol tetradecanedioate).

applications. Isocyanates show a high reactivity toward $\mathrm{OH}$ groups, which facilitates the urethane formation at relatively mild conditions. The final properties and performance of the coating will depend on the selected combination of polyester resin and isocyanate curing agent. Preliminary coating tests from solvent were carried out using the presented polyester resin based on sorbitol, 1,8-octanediol and adipic acid (entry $\mathbf{b}$, Table 1 ). Different curing agents were used, as depicted in Scheme 4:

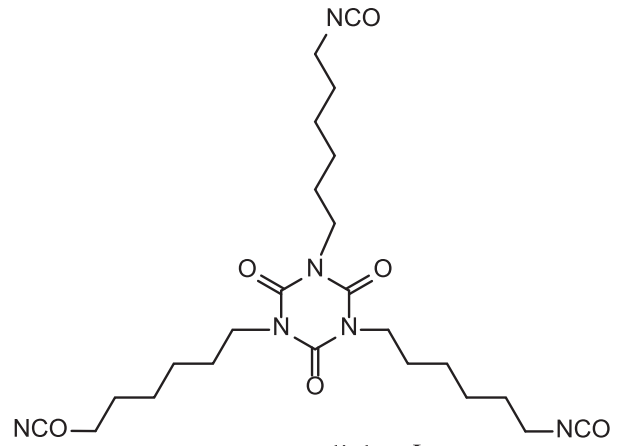

cross-linker $I$

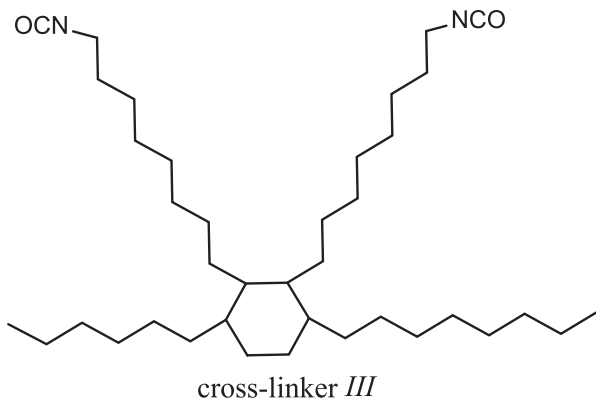

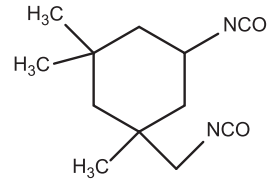

cross-linker $I I$<smiles>CCCCCC(C(=O)OCC)[N+](=O)[O-]</smiles>

cross-linker $I V$

Scheme 4. Conventional cross-linkers: I (trimer of hexamethylene diisocyanate; trade name. Desmodur N3600, approximate structure); II (isophorone diisocyanate, IPDI); III (dimer fatty acid-based diisocyanate, DDI, approximate structure); IV (ethyl ester lysine diisocyanate, EELDI). 
Desmodur N3600 (trade name for an isocyanurate trimer of hexamethylene diisocyanate, cross-linker I), EELDI (ethyl ester L-lysine diisocyanate, cross-linker II), IPDI (isophorone diisocyanate, cross-linker III) and DDI (dimer fatty acid-derived diisocyanate, cross-linker IV). EELDI and DDI have been selected to study their applicability as renewable diisocyanates in PU synthesis. DDI is a vegetable oil-based product from BASF while EELDI is derived from the amino acid lysine [43]. The best conditions to prepare a good coating and the corresponding curing procedure were evaluated. Different solvents were tested: only chloroform dissolves the polymer at room temperature but the resulting coatings were not satisfactory in terms of film appearance, as inhomogeneous films were formed. Other solvents such as acetone, NMP, dioxane and dimethyl formamide were tested at $80^{\circ} \mathrm{C}$, at which temperature the polyol melts and can be dissolved and mixed with the other components to obtain a homogeneous mixture of the cross-linker and the polymer resin. To avoid recrystallization of the polymer in the obtained mixture before curing, the coatings were applied on heated aluminum Qpanels using a doctor blade heated to $80^{\circ} \mathrm{C}$. Directly after coating, the aluminum Q-panel was placed in an oven for solvent removal and curing at $180{ }^{\circ} \mathrm{C}$ under $\mathrm{N}_{2}$ flow for $30 \mathrm{~min}$.

After curing with the different cross-linkers, the resulting polyurethanes were tested for their solvent rubbing resistance, their reverse impact resistance and their pencil hardness.

Table 7 shows a summary of the most important coating properties for the obtained polyurethanes.

Different stoichiometries of the cross-linker I relative to the polyester resin were tested in order to find the minimum amount of isocyanate functionalities required to obtain a well cured polymer network to satisfy the coating tests (formulations F1-F3). When the polyester was cured at a ratio $\mathrm{OH}: \mathrm{NCO}=1: 0.5(\mathrm{~F} 3)$, a loss in performance with respect to the other two ratios (F1 and F2) was observed, indicating incomplete network formation. Although the flexibility arising from the structure of cross-linker I appears to enhance the mechanical properties, F3 shows poor solvent resistance and hardness. To ensure proper network formation and to evaluate cross-linkers having two and not three isocyanate functionalities, all the others coatings were formulated using a stoichiometry of the isocyanate group with respect $\mathrm{OH}$-groups of higher than 0.5 (F4 and F5) or even higher than 1 (i.e. an excess of isocyanate groups) as in the case of F6.
Since the polyester was cured with all different crosslinkers (F4, F5 and F6), it was possible to evaluate the effect of the cross-linker structure on the final performance of the obtained coating. The most striking difference is the reduced coating performance when using DDI. The deteriorated solvent resistance may be due to a moderate network formation, which may in turn be caused by the relatively low purity of this compound compared to the other curing agents. This may also influence the impact resistance, which is poor. However, poor miscibility of the curing agent and the polymer resin as well as the higher film thickness may also play a role here. Although the network can withstand a rapid deformation for all different curing agents as well as the acetone double rub test, some difference in behavior related to the hardness is observed. Looking at F4, F5 and F6, the hardness decreased when the bifunctional cross-linkers (cross-linkers II, III and IV) were used. However, the fast deformation appears to be sufficient and may be improved by the flexible structure of the curing agent.

For EELDI, it is known that the reactivity of the two isocyanate functional groups is not equal [44] which can have some negative effect on the final curing. It is possible that its poor performance is due to incomplete curing at the selected conditions. Some improvements can be obtained by tuning the curing protocol in order to find the best conditions for each combination of polyester and cross-linker.

It is important that the polymer resins not only have a proper low molecular weight to ensure a high concentration of end- and side-groups available to react with diisocyanates, but also the location of these functional groups is relevant. In fact, during network formation some dangling chains can be formed if the functional groups are present close to one chain end only. Dangling chains, which are chains of different length only connected to the network on one side, do not contribute to the strength of the network, which can explain the poor solvent and impact resistance observed for some systems [45].

In conclusion, it can be observed that the sorbitol-based poly(ester urethane) coatings cured with the presented cross-linkers show good performance in terms of solvent resistance and mechanical properties. The high crystallinity of the polyesters has an effect on the appearance and on the final performance of the coatings. When the crystallization is (partly) prevented or retarded by the cross-linking, amorphous coatings are formed and the final film looks transparent and exhibits a good solvent resistance, as is the case for formulations F1-F6.

Table 7

Coating properties of sorbitol-based poly(ester urethane)s applied from solution.

\begin{tabular}{|c|c|c|c|c|c|c|c|c|c|}
\hline Resin & Film & $\begin{array}{l}\text { Curing } \\
\text { agent }\end{array}$ & $\mathrm{OHV}^{\mathrm{a}}$ & $\begin{array}{l}\text { Ratio } \\
(\mathrm{OH}: \mathrm{NCO})\end{array}$ & $\begin{array}{l}\text { Solvent for } \\
\text { casting }\end{array}$ & $\begin{array}{l}\text { Acetone resistance }^{\mathrm{b}} \\
\text { [d.r. 100] }\end{array}$ & $\begin{array}{l}\text { Impact test }{ }^{\mathrm{b}}(1 \mathrm{~kg} \\
79 \mathrm{~cm})\end{array}$ & $\begin{array}{l}\text { Av. Film thickness } \\
{[\mu \mathrm{m}]}\end{array}$ & $\begin{array}{l}\text { Pencil } \\
\text { hardness }\end{array}$ \\
\hline \multirow{6}{*}{$\begin{array}{l}\text { b Adipic } \\
\text { acid + sorbitol } \\
\quad+1,8-\mathrm{OD}\end{array}$} & $\mathrm{F} 1$ & I & 80.3 & $1: 1.1$ & Acetone & + & + & 30.9 & $\mathrm{~F}$ \\
\hline & $\mathrm{F} 2$ & I & 80.3 & $1: 0.8$ & Acetone & + & + & 22.9 & $\mathrm{~F}$ \\
\hline & F3 & I & 80.3 & $1: 0.5$ & Acetone & - & + & 33.4 & $5 B$ \\
\hline & F4 & II & 80.3 & $1: 0.8$ & Acetone & + & + & 30.8 & $3 B$ \\
\hline & F5 & III & 80.3 & $1: 0.8$ & Chloroform & $+1-$ & - & 64.4 & $5 B$ \\
\hline & F6 & IV & 80.3 & $1: 1.1$ & Acetone & + & + & 35.2 & $5 B$ \\
\hline
\end{tabular}

\footnotetext{
${ }^{\text {a }}$ Values based on potentiometric titration and expressed in $\mathrm{mg} \mathrm{KOH} / \mathrm{g}$.

b $+=$ good, $\pm=$ moderate and $-=$ poor.
} 
The pencil harness test shows that, except for F1 and F2, all coatings appear to be quite soft. This is caused by the low $T_{\mathrm{g}}$ values of the polyesters which are below room temperature even after curing. After optimization such coatings could be made suitable for soft touch applications.

DSC measurements were performed to determine the thermal transitions of the obtained poly(ester urethane)s after curing. Through the formation of a network, the amorphous phase of the system increases and as shown in Fig. 6, a decrease of the melting temperature and a strong decrease of the enthalpy value can be observed. This effect can be evaluated also by X-ray diffraction studies. In Fig. 7, poly(1,8-octanediol-co-sorbitol adipate) (entry b, Table 1) shows a crystallinity before curing of around $60 \%$ [15]. After a successful curing experiment, the amorphous phase was increased and the degree of crystallinity decreased to $25 \%$. First of all, the addition of the cross-linker of course will decrease the crystallinity through dilution. When the ratio between cross-linker and polymer is $\mathrm{OH}: \mathrm{NCO}=1: 1.1$, the maximum crystallinity should decrease to $48 \%$. Since we could observe a decrease to

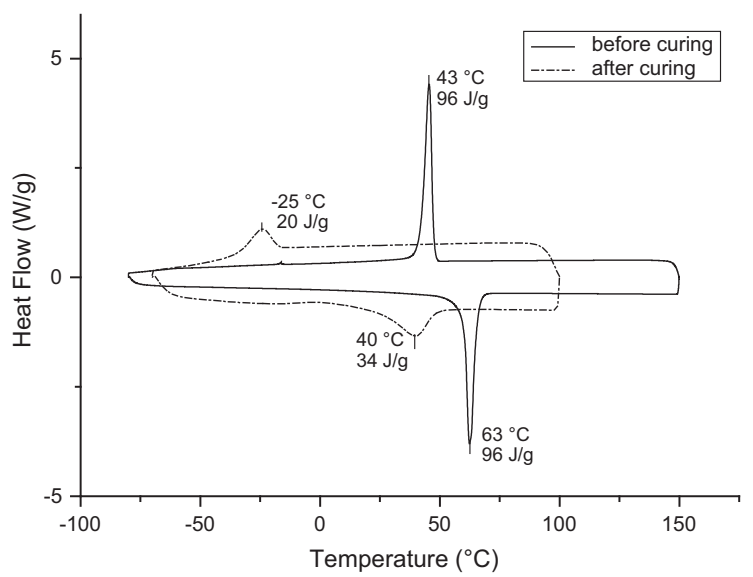

Fig. 6. DSC thermogram of entry b, Table 1 sorbitol-based polyester before curing (solid line); DSC thermogram F1, Table 6 after curing with cross-linker I (dashed line).

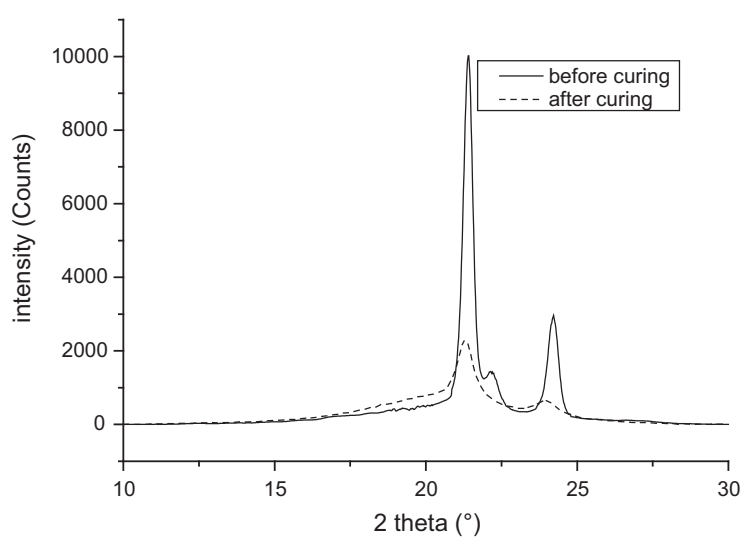

Fig. 7. X-ray pattern for poly(1,8-octanediol-co-sorbitol adipate) (entry b, Table 1) before and after curing (F1).
$25 \%$, the formation of the network is responsible for the remaining $23 \%$ crystallinity decrease. The decrease of the crystallinity is indeed reflected in the clear and transparent appearance of the coating after curing.

From this point on different combinations of monomers can be evaluated in order to synthesize resins with lower crystallinities and possibly higher $T_{\mathrm{g}}$ values, e.g. by introducing diols with an odd number of atoms (e.g. 1,9-nonanediol) or by the introduction of more rigid, asymmetric comonomers such as the sorbitol-derive isosorbide, respectively.

\section{Conclusion}

In this paper, a series of novel sorbitol-based polyesters was prepared from bio-based monomers (sorbitol, 1,10decanediol and several dicarboxylic acids). The synthetic procedure was adapted based on the composition of the monomer mixture, especially in terms of the initial temperature at which a homogeneous reaction mixture was obtained. Due to the combination of decreasing polarity of the aliphatic diols and dicarboxylic acids compared to sorbitol and the different activity of CALB toward apolar aliphatic monomers $v s$. the very polar sorbitol, the synthesis revealed to be quite challenging. Nevertheless, the polymers were successfully synthesized with a final targeted $M_{\mathrm{n}}$ between 4 and $6 \mathrm{~kg} / \mathrm{mol}$ and a yield comparable to other lipase-catalyzed polycondensation reactions. Indication for the incorporation of sorbitol into the copolyesters were obtained by potentiometric titration, showing high $\mathrm{OH}$ values for these polyesters. Furthermore, a qualitative analysis of the sorbitol implemented in the polyesters was obtained through MALDI-ToF-MS, indicating the presence of two distributions in which sorbitol was present. Even at the optimal polymerization conditions, the maximum amount of the sorbitol incorporated into the polyesters revealed to be $53 \mathrm{~mol} \%$ of the initial feed, as determined by inverse gated ${ }^{13} \mathrm{C}$ NMR. Through ${ }^{31} \mathrm{P}$ NMR, the selectivity of CALB for the primary relative to the secondary alcohol groups of the sorbitol unit was investigated. It appears that at the described conditions, CALB shows a preference for the primary alcohols, in accordance with early published work. The obtained polyesters show suitable properties for the use as solvent-borne coating resins. One of the resins were cured using different di- and polyisocyanates. The obtained polyurethane coatings showed good solvent resistance and good mechanical properties, proving the formation of a cured network. A decrease of the crystallinity of the coatings due to network formation was observed by X-ray diffraction and DSC. Due to the low $T_{\mathrm{g}}$ of the copolyester polyols, the obtained poly(ester urethane) coatings are soft materials, which might make these coating suitable for soft touch applications.

\section{Acknowledgements}

This work was carried out as part of the European Union FP7 Marie Curie Initial Training Network (ITN) REFINE (289253). We thank Martin van Nus (DSM Coating Resins) for analytical support, Aritz Laiseka Merino (B.Sc., Univer- 
sity of The Basque Country) for his synthetic contributions, Amy Goddard and Derek Irvine (University of Nottingham) for sharing their expertise regarding ${ }^{31} \mathrm{P}$ NMR, Marco Hendrix, Marko Nieuwenhuizen and Martin Fijten (TU/e) for their help with X-ray diffraction measurements, 2D-NMR spectroscopy and size-exclusion chromatography, respectively. Cognis and Roquette Frères are gratefully acknowledged for supplying the renewable monomers free of charge.

\section{References}

[1] Feng X, East AJ, Hammond WB, Zhang Y, Jaffe M. Polym Adv Technol $2011 ; 22: 139$.

[2] Bozella JJ, Petersen GR. Green Chem 2010;12:539.

[3] Mantzari G, Raphaelides SN, Exarhopoulos S. Carbohydr Polym 2010;79:154.

[4] Raquez J-M, Deléglisea M, Lacrampea M-F, Krawczaka P. Prog Polym Sci 2010;35:487.

[5] Kobayashi H, Ohta H, Fukuoka A. Catal Sci Technol 2012;2:869.

[6] Kobayashi H. Macromol Rapid Commun 2009;30:237.

[7] Zaks A, Klibanov AM. Science 1984;224:1249.

[8] Veld MAJ, Palmans ARA. Advances in polymer science. Berlin; 2010. p. $55-78$.

[9] Kulshrestha AS, Gao W, Gross RA. Macromolecules 2005;38:3193.

[10] Kademi A, Leblanc D, Houde A. In: Pandey A, editor. Concise encyclopedia of bioresource technology. Binghamton, NY: Haworth Press; 2004. p. 552-60.

[11] Zhaozhong J. Biomacromolecules 2008;9:3246.

[12] Yu Y, Wu D, Liu C, Zhao Z, Yang Y, Li Q. Process Biochem 2012;47:1027.

[13] Jiang Y, Woortman A, van Ekenstein G, Loos K. Biomolecules 2013;3:461.

[14] Gross RA, Ganesh M, Lu W. Trends Biotechnol 2010;28:435.

[15] Fu H, Kulshrestha AS, Gao W, Gross RA, Baiardo M, Scandola M. Macromolecules 2003;36:9804.

[16] Kumar A, Kulshrestha AS, Gao W, Gross RA. Macromolecules 2003:36:8219.

[17] Enzyme-catalyzed polycondensation, by Gross, Richard A.; Kumar, Ajay; Kalra, Bhanu, from U.S. Pat. Appl. Publ. (2004), US 20040019178 A1 20040129.

[18] Kobayashi S, Uyama H, Tsujimoto T, Kuwabara M. Polym Prepr 2007; $48: 830$.

[19] Wicks ZW. Coatings, Kirk-Othmer encyclopedia of chemical technology. New York: John Wiley \& Sons Inc.; 2000. p. 77.
[20] Global industrial analysis-GIA

[21] http://www.coatingsworld.com/contents/view_market-research/ 2014-07-11/global-polymeric-polyols-market-expected-to-reach(accessed 16.09.14).

[22] Dais P, Spyros A. Magn Reson Chem 2007;45:367.

[23] Noordover BAJ, Haveman D, Duchateau R, van Benthem RATM, Koning CE. J Appl Polym Sci 2011;121:1450.

[24] Zhou Z, He Y, Qiu X, Redwine D, Potter J, Cong R, et al. Macromol Symp 2013;330:115.

[25] Uyama H, Kobayashi S. Adv Polym Sci 2006;194:133.

[26] Mahapatro A, Kalra B, Kumar A, Gross RA. Biomacromolecules 2003;4:544.

[27] Azim H, Dekhterman A, Jiang ZZ, Gross RA. Biomacromolecules 2006; 7:3093.

[28] Kim DY, Dordick JS. Biotechnol Bioeng 2001;76:200.

[29] Kumar A, Gross RA. Biomacromolecules 2000;1:133.

[30] Kricheldorf HR, Schwarz G. Macromol Rapid Commun 2003;24:359.

[31] American Society for Testing and Materials. Standard test methods for hydroxyl groups using acetic anhydride acetylation. ASTM E22210. ASTM, West Conshohocken, 2010.

[32] American Society for Testing and Materials. Standard test methods for testing polyurethane raw materials: determination of hydroxyl numbers of polyols. ASTM D4274-11. ASTM, West Conshohocken, 2011.

[33] Official Methods and Recommended Practices of the American Oil Chemists' (1997) Society. 4th ed. American Oil Chemists' Society, Champaign, 1993, revised (1997).

[34] Jiang Z-H, Argyropoulos DS, Granata A. Magn Reson Chem $1995 ; 33: 375$

[35] Hatzakis E, Dais Photis. J Am Oil Chem Soc 2007;84:615.

[36] Kumar A, Gross RA. J Am Chem Soc 2000;122:11767.

[37] Fradet A, Tessier M. John Wiley \& Sons, Inc., Hoboken, NJ, USA, 2003.

[38] Chaudhary AK, Beckman EJ, Russell AJ. Biotechnol Bioeng 1997;55:227.

[39] Kulschewski T, Sasso F, Secundo F, Lotti M, Pleiss J. J Biotechnol 2013;168:462.

[40] Lee CS, Ru MT, Haake M, Dordick JS, Reimer JA, Clark DS. Biotechnol Bioeng 1998;57:686.

[41] Binns F, Roberts SM, Taylor A, Williams CF. J Chem Soc Perkin Trans 1 1993:899.

[42] Diaz A, Katsarava R, Puiggalí J. Int J Mol Sci 2014;15:7064.

[43] Storey RF, Wiggins JS, Puckett ADJ. Polym Sci A Polym Chem 1994;32:2345.

[44] Li Y, Noordover BAJ, van Benthem RATM, Koning CE. ACS Sustain Chem Eng 2004;2:788.

[45] Dušek K, Dušková-Smrčková M, Fedderly JJ, Lee GF, Lee JD, Hartmann B. Macromol Chem Phys 2002;203:1936. 